\title{
REKONCEPTUALIZACIJA TRANSFORMACIJSKIH PROCESA NA PERIFERIJI OSMANSKOG CARSTVA: FILURIJA I PRIJELAZ NA REŽIM NATURALNE DESETINE U AGRARNOJ EKONOMIJI OSMANSKE BOSNE, C. 1699-1852.
}

\author{
Fahd Kasumović \\ Filozofski fakultet Univerziteta u Sarajevu \\ fahd.kasumovic@ff.unsa.ba
}

\begin{abstract}
Apstrakt: U ovom radu preispituju se dominantne historiografske predodžbe o transformacijskim procesima u Osmanskom Carstvu $\mathrm{u}$ periodu od kraja 17. do polovine 19. stoljeća. Rad pokazuje da postojeće ideje o navedenoj problematici u svjetskoj osmanistici nisu dostatne da se razumiju svi vidovi strukturalnih promjena u osmanskoj Bosni, te da je potrebno rekonceptualizirati ideju šta sve treba smatrati transformacijskim procesom u osmanskom kontekstu. Na primjerima iz arhivske građe pokazano je da prilikom diskusija o navedenim pitanjima treba uzeti $\mathrm{u}$ obzir i varijacije finansijskog sistema u osmanskim provincijama, te da je u Bosni neophodno razmotriti i proces ukidanja filurije i paušalnih novčanih daća, kao i prijelaz na režim naturalne desetine, koji se u Bosanskom ejaletu odvijao u različitim fazama. Navedeni proces imao je dugu povijest, a u ovom su istraživanju analizirane one faze koje su se desile u periodu od kraja 17. do polovine 19. stoljeća. Rad obrađuje uzroke koji su doveli do navedenog procesa, strukturalne promjene koje je on proizveo $u$ provincijskim finansijama, kao i njegove društveno-ekonomske posljedice. Metodom kritičke analize pokazano je da ova pitanja nisu bila adekvatno istražena, prepoznata ni istumačena u literaturi koja se bavila ekonomskom poviješću osmanske Bosne, kao i da se u historiografiji uopće ne govori o prijelazu na režim desetine kao o dugotrajnom procesu s različitim fazama.
\end{abstract}


Ključne riječi: Osmansko Carstvo, Bosna i Hercegovina, ekonomska povijest, finansije, transformacijski procesi, porezna politika, agrarna ekonomija, strukturalne promjene, Vlasi

\begin{abstract}
This paper re-examines the dominant historiographic images on the transformation processes in the Ottoman Empire from the end of the $17^{\text {th }}$ century to the early 1850 s. Together with critically evaluating the main developments on this topic in the Ottoman studies, it argues that the ideas presented by the acclaimed contributors in this field are insufficient to explain all of the structural changes that occurred in the Ottoman state finance, and in the economies of the frontier regions. The author argues that the historiographic idea of what should be considered under the umbrella of transformation processes needs to be re-conceptualized and adjusted to the local financial contexts of the various regions of the Ottoman Empire. When speaking of the fiscal transformation in Ottoman Bosnia, it is necessary to take into account various governmental decisions to abolish the filûrî tax as well as the lump-sum payments, and to substitute them with the in-kind obligation-the tithe. Based on the unpublished primary sources, this paper suggests that the mentioned phenomena should be considered a part of a wider transformation process, with different historical phases. This research focuses upon its sequences that spanned from the end of the $17^{\text {th }}$ century to the early 1850s. After explaining the political reasoning that stood behind the decision to revoke the filûri tax and to substitute it with the tithe, this paper researches and explains the consequences of the mentioned financial measure, starting from the structural changes in the provincial finances to the impact it had in the wider social and economic framework.
\end{abstract}

Keywords: Ottoman Empire, Bosnia and Herzegovina, economic history, finance, transformation processes, taxation policy, agricultural economy, structural changes, the Vlachs.

Dominantni historiografski narativ o dugom i sigurnom opadanju Osmanskog Carstva nakon "zlatnog" 16. stoljeća i pretpostavljenom indolentnom odnosu centralnih i provincijskih vlasti u rješavanju nagomilanih društvenih i državnih problema, više puta je tokom posljednjih nekoliko decenija bio kritički preispitivan te se, umjesto njega, u relevantnoj znanstvenoj literaturi sve češće susreću kontranarativi koji, pored nezaobilaznih 
Fahd Kasumović, Rekonceptualizacija transformacijskih procesa na periferiji Osmanskog Carstva: filurija i prijelaz na režim naturalne desetine u agrarnoj ekonomiji osmanske Bosne, c. 1699-1852.

kriznih situacija, ukazuju na aktivnu državnu strategiju saniranja krize, promjene institucionalnog okvira, kao i s njima povezane transformacijske procese na polju društveno-ekonomskih odnosa. Autori koji su se bavili ovom problematikom ključ za opstanak osmanske države pronašli su u vojnim i fiskalnim reformama, kao i sposobnosti centralne vlasti i vojnopolitičke elite da uspješno integriraju nezadovoljne pripadnike vojničke klase i vodeće društvene aktere u provincijama, te da ih stimuliraju u mjeri koja je bila potrebna, kako bi stajali na braniku imperijalnih interesa. Fiskalni moment u svemu tome bio je posebno važan, budući da je uspješna ekstrakcija državnih prihoda bila neophodna za funkcioniranje temeljnih državnih službi, te su u literaturi, kao važni dokazi koji upućuju na fiskalnu transformaciju, istaknuti uvođenje novih poreza, kao i promjene u metodama ubiranja starih podavanja. Ključni argumenti koji se u ovom pogledu spominju u relevantnim radovima bili su pretvaranje pojedinih naturalnih izvanrednih poreza u redovne novčane daće, što je ostvareno tokom 17. stoljeća, reforma ubiranja glavarine (1691), uvođenje doživotnog zakupa državnih prihoda (1695), promjena sistema finansiranja provincijskih namjesnika kroz uvođenje novih poreza pod imenom ratna i mirnodopska pomoć, krajem druge decenije 18. stoljeća, zavođenje niza novih daća pod skupnim imenom "troškovi vilajeta" (masârıf-ı vilâyet), te nove metode razrezivanja navedenih poreza kroz suradnju kadija i lokalne elite (ayân). ${ }^{1}$

\footnotetext{
${ }^{1}$ Halil İnalc1k, "Military and Fiscal Transformation in the Ottoman Empire, 1600-1700", Archivum Ottomanicum, Wiesbaden: Harrasowitz, 1980, sv. 6, 283-337; Suraiya Faroqhi, "Crisis and Change, 1590-1699", u: An Economic and Social History of the Ottoman Empire: Volume 2: 1600-1914, ur. Halil İnalcık i Donald Quataert, Cambridge: Cambridge University Press, 1997, 411-636; Karl Barbir, "The Changing Face of the Ottoman Empire in the Eighteenth Century: Past and Future Scholarship", u: Oriente Moderno, Nuova serie, Rim: Istituto per l'Oriente C. A. Nallino, 1999, sv. 18 (79), br. 1, 253-267; Karen Barkey, The Empire of Difference: The Ottomans in Comparative Perspective, Cambridge: Cambridge University Press, 2008, 1-342; Linda Darling, Revenue-Raising and Legitimacy: Tax Collection and Finance Administration in the Ottoman Empire, 1560-1660, Leiden: E. J. Brill, 1996, 1-368; Gábor Ágoston, "Military Transformation in the Ottoman Empire and Russia, 1500-1800", Kritika: Explorations in Russian and Eurasian History, sv. 12, br. 2, (Special Issue: Models on the Margins Russia and the Ottoman Empire), Bloomington: Slavica Publishers, 2011, 281-319; Yavuz Cezar, Osmanl Maliyesinde Bunalım ve Değişim Dönemi: (XVIII. yy dan Tanzimat'a Mali Tarih, Istanbul: Alan Yayıncılık, 1986, 1-417.
} 
Navedene historiografske teze o fiskalnoj transformaciji kao o postepenom procesu adaptacije državne strategije ubiranja prihoda i politike javne potrošnje zahtjevima vremena i prostora, odnosno prilagodbe kriznim situacijama, koje su potresale državu i društvo, daju se potkrijepiti primarnim izvorima, te ih je moguće primijeniti na mnoge oblasti u Osmanskom Carstvu, uključujući i Bosanski ejalet. Međutim, literatura o osmanskoj fiskalnoj transformaciji koja je na internacionalnoj pozornici privukla najviše pažnje, pati od nedostataka koji onemogućavaju pravilno shvaćanje složenosti transformacijskih procesa u osmanskom društveno-ekonomskom i političkom kontekstu. Na prvom mjestu, primjećuje se da se primjeri na koje se pozivaju autori navedenih studija odnose na mali broj provincija. Kada se ima u vidu ogromna površina Osmanskog Carstva, kao i dokazana raznolikost fiskalnih praksi u različitim administrativno-teritorijalnim jedinicama, onda se s pravom nameće potreba da se temeljitije istraži arhivska građa, kako bi se moglo doći do zaključaka koji bolje oslikavaju raznolikost procesa fiskalne transformacije na različitim terenima, što možemo označiti kao regionalne različitosti. Nije to važno samo radi donošenja argumentiranih zaključaka o povijesnim okolnostima u pojedinim osmanskim provincijama, nego i zbog potrebe da se kvalitetnije shvati i istumači politika državnog centra prema perifernim oblastima.

Osnovni cilj ovog rada je pokazati da navedene postavke iz eminentnih historiografskih djela o transformacijskim procesima u Osmanskom Carstvu nisu dovoljne da objasne sve ključne promjene u provincijskim finansijama Bosanskog ejaleta - osmanskoj pograničnoj oblasti i periferiji svijeta islama - u periodu od kraja 17. do polovine 19. stoljeća, te da je nužno rekonceptualizirati ideju šta se sve treba ubrajati među indikatore transformacijskih procesa u navedenom razdoblju. Ovaj rad nastoji pokazati da pored diskusije o fiskalnoj transformaciji na području Bosanskog ejaleta, uzevši u obzir ranije nabrojane elemente koji se susreću u historiografiji, treba uzeti u obzir i proces ukidanja određenih tradicionalnih novčanih podavanja - "vlaških poreza" (rüsûm-ı Eflâkân), odnosno filurije (resm-i 
Fahd Kasumović, Rekonceptualizacija transformacijskih procesa na periferiji Osmanskog Carstva: filurija i prijelaz na režim naturalne desetine u agrarnoj ekonomiji osmanske Bosne, c. 1699-1852.

filûrî ili resm-i filorî), ${ }^{2}$ ali i daća određenih paušalnim metodom (ber-vech$i$ makt $\hat{u}^{c}$ ) - te da će znanja o transformacijskim procesima biti potpunija ukoliko se detaljnije istraži prevođenje zemljišta, koja su plaćala navedena novčana podavanja na režim naturalne desetine (öşr).

$\mathrm{Za}$ razliku od navedene historiografske literature o osmanskim transformacijskim procesima, koja je upotpunosti izostavila ukidanje filurije i prijelaz na režim desetine u 18. i prvim decenijama 19. stoljeća kao pojavu značajnu za razumijevanje fiskalne transformacije u Osmanskoj državi, u radovima u čijem se fokusu nalazilo područje Bosanskog ejaleta moguće je o tome susresti određene informacije. Međutim, historičari su najviše pažnju posvećivali stanju osmanske agrarne ekonomije u 15. i 16. stoljeću, kao i promjenama koje su se u njoj desile u vrijeme tanzimatskih reformi, polovinom 19. stoljeća, ${ }^{3}$ tako da za razdoblje od ca. 1604. do 1848. postoje samo rudimentarni podaci. Došlo se do važne spoznaje da su sva zemljišta u Bosanskom ejaletu bila polovinom 19. stoljeća prevedena na režim naturalne desetine, ali se $\mathrm{u}$ historiografiji propustilo o tome raspravljati kao

${ }^{2}$ Ovaj porez u nauci se ponekad spominje i kao resm-i filori. Ovdje se preferira čitanje u obliku resm-i filûrî, u skladu s načinom na koji je čitanje navedenog izraza zabilježeno u Redhouseovom rječniku s kraja 19. stoljeća, objavljenom u Istanbulu. James W. Redhouse, A Turkish and English Lexicon: Shewing in English the Significations of the Turkish Terms, Constantinople: American Mission, 1890, 1396.

${ }^{3}$ Podaci o ovome mogu se pronaći u: Jusuf Mulić, "Društveni i ekonomski položaj Vlaha i Arbanasa u Bosni pod osmanskom vlašću", u: Prilozi za orijentalnu filologiju, sv. 51, Sarajevo: Orijentalni institut, 2011, 129-134; Vjeran Kursar, "Being an Ottoman Vlach: On Vlach Identity (Ies), Role and Status in Western Parts of the Ottoman Balkans (15th-18th Centuries)", u: OTAM, sv. 34, Ankara: Ankara Üniversitesi Basımevi, 2013, 115-161; Nenad Moačanin, Turska Hrvatska, Zagreb: Matica Hrvatska, 1999, 121-122; Snježana Buzov, "Vlasi u bosanskom sandžaku i islamizacija", u: Prilozi za orijentalnu filologiju, sv. 41, Sarajevo: Orijentalni institut, 1991, 99-111; Ahmed S. Aličić, "Desetina u Bosni polovinom XIX vijeka", u: Prilozi, sv. 16, br. 17, Sarajevo: Institut za istoriju, 1980, 129-174; Nedim Filipović, "Pogled na osmanski feudalizam", Godišnjak Istorijskog društva Bosne i Hercegovine, sv. 4, Sarajevo: Istorijsko društvo Bosne i Hercegovine, 1952, 5-146; Nedim Filipović, "Vlasi i uspostava timarskog sistema u Hercegovini", Godišnjak, sv. 12/10, Sarajevo: Centar za balkanološka istraživanja, ANUBiH, 1974, 127-221; Fahd Kasumović, "Osmanska agrarna politika i nadmetanje za zemlju u jugoistočnoj Evropi (analiza čifluka u Bosanskom sandžaku od uspostavljanja osmanske vlasti do početka 17. stoljeća)", u: Anali Gazi Husrev-begove biblioteke, sv. 35, Sarajevo: Gazi Husrev-begova biblioteka, 2014, 93-150. 
o dužem procesu čija se samo završna faza odigrala u vrijeme tanzimatskih reformi. ${ }^{4}$ Štaviše, zanimljivo je da nijedan od autora koji spominju ovu pojavu uopće ne koristi izraz proces, za razliku od onoga što se predlaže u ovom radu te bilo čim ne pokazuju da su imali informacije o fazama tog procesa, koje su se desile krajem 17. i u prvoj polovini 18. stoljeća. Neki su autori imali podatke da je u drugoj polovini 18. stoljeća bilo pokušaja spahija i kapetana da se prevedu određena zemljišta na sistem desetine, a moguće je susresti i konstatacije da je isto pokušavala i država. ${ }^{5}$ No, nekih značajnih i detaljnijih informacija o tome nema u literaturi, a pojedinim autorima je čak i to promaklo, pa su prve početke osmanskih nastojanja da filuriju zamijene desetinom pogrešnom vidjeli tek tridesetih godina 19. stoljeća. ${ }^{6}$

Kada se usporede navedeni rezultati historiografije s onim što je zabilježeno u sačuvanoj arhivskoj građi, zaključuje se da postoji niz otvorenih pitanja i mogućnosti u vezi s tumačenjem procesa ukidanja vlaških poreza i paušalnih podavanja te prijelazom na režim naturalne desetine u Bosanskom ejaletu. Na prvom mjestu, potrebno je dokazati postojanje procesa i istražiti njegove ključne faze, objasniti politički i finansijski rezon, koji je doveo do državne odluke o promjeni režima ubiranja državnih prihoda, zatim interakciju centralne i provincijskih vlasti u vezi sa rješavanjem ovih pitanja, kao i posljedice koje je promjena u režimu ubiranja podavanja imala po strukturu provincijskih finansija i ekonomske prilike u Bosanskom ejaletu. Također, od ključnog je značaja istražiti posljedice koje je donošenje ove odluke imalo za uspješno funkcioniranje vojno-administrativnog aparata, ali i njen utjecaj na živote društvenih elita, koje su zakupljivale

\footnotetext{
${ }^{4}$ A. Aličić, "Desetina", 129-174.

${ }^{5}$ Avdo Sućeska, "Pokušaji muslimanske raje u Bosni da se oslobode rajinskog statusa u XVIII stoljeću”, u: Dijalog - Časopis za filozofiju i društvenu teoriju, br. 1-2, 2003, 195; Avdo Sućeska, "Uticaj austro-turskih ratova na opterećivanje stanovništva u Bosni u XVIII stoljeću”, u: Godišnjak Pravnog fakulteta u Sarajevu, sv. 27, Sarajevo: Pravni fakultet u Sarajevu, 1980, 200-201.

${ }^{6}$ Ovu ideju iznosi Truhelka. Usp. Ćiro Truhelka, “O podrijetlu žiteljstva grčkoistočne vjeroispovijesti u Bosni i Hercegovini (1941)”, u: Vlasi u starijoj hrvatskoj historiografiji, ur. Ivan Mužić, Split: Muzej hrvatskih arheoloških spomenika, 2010, 125-126.
} 
prihode od filurije i desetine te posljedice po slojeve stanovništva, koje su u svom posjedu držale zemljišta podložna plaćanju podavanja. Glavni dio ovog rada posvećen je pružanju odgovora na navedena pitanja i detaljnom obrazlaganju značaja ukidanja vlaških poreza i prijelaza na režim desetine za bolje razumijevanje transformacijskih procesa na području Bosanskog ejaleta u periodu od kraja Bečkog rata do polovine 19. stoljeća.

\section{Historijski background: Kako se pripremala pozornica za transformacijske procese 18. stoljeća?}

Krajem 17. i početkom 18. stoljeća, osmanska je centralna vlast, u suradnji s provincijskim vlastima, započela u Bosanskom ejaletu provođenje akcije, koja je izuzetno važna za razumijevanje transformacijskih procesa na navedenom području - na velikom broju državnih zemljišta, uključenih u zakupne jedinice poznate pod imenom mukate ( $\left.m u k a \hat{a} t a^{c} a\right)$, ukinula je novčanu filuriju (resm-i filûrî), kao i paušalnim metodom utvrđena podavanja $\left(m a k t \hat{u}^{c}\right)$, te je umjesto toga zavela obavezu plaćanja naturalne desetine. Navedena akcija bit će detaljno elaborirana u narednom poglavlju; međutim, sadržaj tog dijela rada teško bi se mogao pravilno razumjeti ukoliko se, prije svega, ne predstavi historijska pozadina ubiranja vlaških poreza u 17. stoljeću te ukoliko se ne uzme u obzir društveno-politički kontekst vremena koje je neposredno prethodilo donošenju ovih mjera.

Filurija je izvorno predstavljala naziv za daću koju su plaćale vlaške stočarske zajednice na Balkanu, te se u primarnim izvorima susreće i pod imenom "vlaški porez" (resm-i eflâkiyye; pl. rüsûm-ı eflâkiyye). ${ }^{7}$ Mada se izvorno pod ovom daćom podrazumijevao iznos od jednog dukata, po čemu je ona i dobila ime. Važno je naglasiti da se u jeziku osmanske administracije pod tim istovremeno podrazumijevao i ukupan novčani porez koji je plaćalo svako vlaško domaćinstvo, što je uglavnom bilo znatno više od vrijednosti dukata. ${ }^{8}$ Osmanska vlast je prilagođavala iznose ovog poreza

\footnotetext{
7 "rüsûm-ı eflâkiyye kayd olınan yerler". BOA, TD 533, 536.

${ }^{8}$ Naprimjer, u zakonu za smederevske Vlahe iz 1528. navodi se da je vrijednost filurije bila 45 akči.
} 
zahtjevima vremena i prostora te se o tome mogu susresti brojni podaci u katastarskim popisnim defterima. Također, zanimljivo je da je osmanska vlast na određenim mjestima uvodila filuriju i u zajednicama koje nisu bile označavane kao Vlasi. ${ }^{9}$

Za filuriju se u historiografiji vežu i određene predrasude, koje su rezultat toga što se o ovom porezu promišljalo najčešće iz perspektive ranijih podataka, dok su nedovoljno uzimani u obzir podaci iz druge polovine 16, kao i tekstovi iz 17. stoljeća. Pogrešno je, naprimjer, isključivo vezivati ovaj porez za vlaško domaćinstvo, a zanemarivati činjenicu da je osmanska vlast, osim za domaćinstvo, ovaj porez vezivala i za zemlju. Dokaz za vezivanje filurije za zemlju je podatak da se u pojedinim katastarskim popisnim defterima susreće sintagma "zemljište pod filurijom" (filûrilü yer), ${ }^{10}$ dok se u mnogim popisima, kao što su, između ostalog, popis Bosanskog sandžaka iz 1604. godine, filurija skoro isključivo bilježi na baštine, kao zemljišne jedinice, odnosno na starješine domaćinstava (hâne) koji su navedene baštine držali u svom posjedu. ${ }^{11}$

Filurija je zbog toga imala i određene karakteristike zemljišnih poreza, a najvažnija od njih je ta da svi oni koji drže zemljište podložno određenom porezu trebaju isti i plaćati nezavisno od svojih osobnih karakteristika i identiteta. Zbog toga, posjednici filurijskih zemljišta su mogli biti i muslimani iz reda vojničke klase, koji nisu imali nikakve veze s Vlasima.

Na to su dodana ostala vlaška podavanja koja su raspoređena na domaćinstva, pri čemu se došlo do iznosa od 83, a zatim i do 90 akči, pa je i posljednji iznos do kojeg se došlo na ovaj način bio označen imenom filurija (bi’l-cümle filûrîleri). Dušanka Bojanić (prev.), Turski zakoni i zakonski propisi iz XV i XVI veka za smederevsku, kruševačku i vidinsku oblast, Beograd: Istorijski institut, 1974, 34; BOA, TD 144, 1-2.

${ }^{9}$ Rudari Kreševa plaćali su 1489. godine filuriju na svako domaćinstvo, a daća pod tim imenom zabilježena je iste godine i u Travniku. Ni u jednom od ova dva slučaja nije se radilo o Vlasima. Kada je riječ o Travniku, vlast je zavođenjem filurije, kao povoljnije daće, nastojala spriječiti depopulaciju, jer neki su stanovnici, kako se navodilo, već bili napustili svoja ranija staništa. Navedenom mjerom nastojalo se "pridobiti" (istimâlet) za ostanak preostalo stanovništvo. BOA, TD 24, 6, 74.

10 "filûrilü yerlerün âdet-i eflâkiyye üzere resm-i filûrîsin temâm edâ". BOA, TD 533, 14.

${ }^{11}$ Ovo se može vidjeti na primjeru nahije Kobaš. Amina Kupusović (prev.), Opširni popis Bosanskog sandžaka iz 1604. godine, sv. 4. Sarajevo: Bošnjački institut Zürich - Odjel Sarajevo i Orijentalni institut u Sarajevu, 2000, 465-509. 
Naprimjer, u klasičnim popisima susreću se administrativni dužnosnici, ulema, spahije i različiti vojnici kao posjednici zemlje, ${ }^{12}$ dok je u Bosni u 18. stoljeću moguće susresti muslimanske posjednike čifluka iz reda vojničke klase, koji su držali tapije za zemlju u kojima je otvoreno bilo navedeno da plaćaju filuriju. ${ }^{13}$ Drugim riječima, plaćati vlaški porez, nije nužno značilo da je posjednik bio Vlah, nego da je držao u svom posjedu zemlju podložnu porezu, koji je tradicionalno poiman kao vlaški. Nekada se u prvi plan nije dovodio izraz vlaški porez, nego se samo govorilo da se radilo o filuriji ili o filuridžijama, s tim da su filuridžije mogli biti Vlasi, ali i različite druge skupine koje su plaćale filuriju. ${ }^{14}$

U vezi s tim je i drugi stereotip o filuriji, a to je da je ona isključivo predstavljala stočarski danak. ${ }^{15}$ Navedeni podaci o muslimanskim posjednicima koji su držali zemlju pod filurijom pokazuju da se tu uopće nije radilo o stočarima, pogotovo kada se radi o kasnijem vremenu. Također, treba imati u vidu i da je nekadašnje stočarsko stanovništvo uglavnom bilo registrirano na određenim zemljišnim jedinicama, te da su se mnogi primarno bavili zemljoradnjom. Zbog toga, u 18. stoljeću i jeste bilo moguće izvršiti masovno prevođenje filurijskih baština na naturalnu desetinu. Opravdano je zaključiti da je zemljoradnja bila temeljna privredna grana na takvim zemljišnim jedinicama.

Filurija nije bila jedina novčana daća koja se susreće u defterima u kojima su popisani "vlaški porezi" (rüsûm-ı Eflakân). Osmanska vlast je na pojedinim zemljišnim jedinicama pod imenom makt $\hat{u}^{c}$ nametala određene iznose, koji su mogli biti veći ili manji od filurije koja je bila važeća na određenom području, što je, između ostalog, zavisilo od prinosa i veličine

\footnotetext{
${ }^{12}$ S. Buzov, "Vlasi u bosanskom sandžaku i islamizacija", 109-110.

${ }^{13}$ Prema jednoj tapiji iz 18. stoljeća, koju su izdale osobe koje su upravljale Kobaškom mukatom, Hadži Omer-efendija Đumišić je trebao plaćati filuriju na zemlju koja se nalazila u njegovom posjedu. Đumišići su inače bili ugledna banjalučka porodica čiji su pripadnici držali niz čifluka na ovom području u 18. i 19. stoljeću. GHB, A-4855/T0-607.

14 “an mâl-i rüsûm-1 filûrîciyân”. BOA, MAD.d 4718, 2.

${ }^{15}$ Takav stereotip postoji kod Matkovskog. Usp. Aleksandar Matkovski, "Stočarski danak - filurija”, Arhivski vjesnik, br. 33, Zagreb: Hrvatski državni arhiv, 1990, 71-77.
} 
zemljišnih parcela o kojima je bilo riječ. ${ }^{16}$ Gledano iz pozicije osmanske administracije, makt $\hat{u}^{c}$ je označavao iznos koji je bio nametnut odsjekom, odnosno paušalno, umjesto nekih drugih podavanja. Naprimjer, moguće ga je susresti u vlaškim popisima, te je tom prilikom ponekad bilo navedeno da se radilo o "vlaškom porezu koji je određen odsjekom" (resm-i eflâkiyye ber-vech-i makt $\left.\hat{u}^{c}\right) .{ }^{17}$ Međutim, treba istaći da se nametanje paušalnih podavanja pod imenom makt $\hat{u}^{c}$ ne susreće samo u popisima vlaških domaćinstava i baština nego i u defterima u kojima je popisano zemljoradničko stanovništvo koje nije imalo vlaški status. Također, ovim metodom bila su određena i podavanja koja su, umjesto desetine, bila nametnuta na nizu zemljišnih jedinica koja su nazivana izrazom čifluk, a koje su u svom posjedu držale različite osobe, uključujući i pripadnike vojničke klase te, ponekad, i krupne osmanske dužnosnike. ${ }^{18}$

Odnos vlasti prema ubiranju filurije nije bio konstantan i nepromjenjiv, te su određeni transformacijski procesi u 16. stoljeću mogu primijetiti u Bosni, kao i u susjednim sandžacima. Najpoznatiji indikator jednog takvog procesa je ukidanje posebnog statusa Vlaha, što je podrazumijevalo ukidanje filurije i prevođenje navedene skupine na režim podavanja karakterističan za zemljoradničku raju. Riječ je o obavezi plaćanja desetine i novčanim rajinskim porezima, kao i o podvrgavanju Vlaha plaćanju džizje i poreza na sitnu stoku. Historičari su utvrdili da je osmanska vlast uskoro ponovo uvela filuriju u određenim sandžacima, kao što su Bosanski, Hercegovački

\footnotetext{
${ }^{16}$ Prema jednom popisu Vlaha Bosanskog sandžaka, sastavljenom polovinom 16. stoljeća, za pojedine baštine s paušalno određenim manjim iznosima bilo je zabilježeno da se radilo o neznatnoj količini zemljišta (cuz ${ }^{\curvearrowright} \hat{\imath}$ yerler), koja zbog toga ne bi mogla podnijeti veći iznos podavanja. Za Vlahe Nove Varoši bilo je istaknuto da podavanja plaćaju odsjekom, "u skladu sa svojim mogućnostima" (kudretlerine göre). Na nekim zemljišnim jedinicama bili su ustanovljeni i iznosi veći od filurije od 180 akči koja je u to vrijeme bila uobičajena na području o kojem je bilo riječ. Po svemu sudeći, značilo je to i veće površine od kojih se taj iznos mogao ubrati. Nekada je na ovaj način bilo određivano podavanje za veće zemljišne komplekse koji nisu bili dovoljno naseljeni te ih je trebalo naseliti. BOA, MAD.d 768, 4, 8, 57.

${ }^{17}$ BOA, MAD.d 560, 60.

${ }^{18}$ O tome vidi: N. Filipović, "Pogled na osmanski feudalizam”, 118; F. Kasumović, “Osmanska agrarna politika”, 117-120, 145; N. Moačanin, Turska Hrvatska, 126.
} 
i Kliški, dok se ova mjera pokazala trajnom za teritoriju Zvorničkog sandžaka. ${ }^{19}$ Međutim, ovu konstataciju potrebno je dopuniti te treba istaći da se i u Zvorničkom sandžaku na određenim područjima sjeveroistočne Bosne, izuzetno, još početkom 17. stoljeća susreće daća koja je bila označena imenom filurija. Ona nije bila identična s ranijom vlaškom filurijom, već se radilo o porezu uvedenom kako bi se određena pusta i plavna područja naselila, te da se ne bi gubio državni prihod. ${ }^{20}$

Vrlo malo se zna o sudbini filurije i odsjekom ustanovljenih podavanja nakon početka 17. stoljeća. Osmanski finansijski registri pokazuju da je ona u Bosanskom ejaletu tokom ovog razdoblja predstavljala najveći zabilježeni prihod državne riznice. Naprimjer, u jednom popisu Bosanske riznice (Bosna hazinesi) ${ }^{21}$ iz 1679. godine, koji nije do sada bio korišten u znanstvenim radovima o osmanskim provincijskim finansijama, zabilježeno je da je u prethodnoj 1677/78. prihod od filurije u Bosanskom ejaletu iznosio 4.725.305 akči. Bila je to najveća pojedinačna stavka u ovom finansijskom registru. Ona je činila čak 43,43\% ukupno zabilježenih prihoda, dok su tek iza nje bili prihodi od mukata carskih hasova i džizja, a onda i ostali prihodi. ${ }^{22}$ Navedeno dovoljno govori o tome da je filurija spadala među najznačajnije državne prihode $\mathrm{u}$ Bosanskom ejaletu, a i drugi slični registri iz 17. stoljeća potvrđuju ovu tezu. Potrebno je, ipak, napomenuti da ovakva vrsta obračuna prihoda i rashoda nije kompletna, budući da nije sadržavala podatke o onim podavanjima koja su sakupljana u okviru timarskog sistema, a i tu je jednim manjim dijelom bila zastupljena filurija. Međutim, nesporno je da je ona bila najveća daća među prihodima koje je kontrolirala Bosanska riznica.

\footnotetext{
${ }^{19}$ Adem Handžić, Tuzla i njena okolina, Sarajevo: Svjetlost, 1975, 107.

${ }^{20}$ Npr. u Opširnom popisu Zvorničkog sandžaka, u selu Goduša, spominje se 1548. filurija koja je bila zamjena za desetinu, ispendžu i ostale pristojbe (resm-i filuri-yi bedel-i öşr ve ispence ve sââr rüsûm). Također, filurija se spominje kao daća u više drugih sela u nahiji Nenavište u popisu iz 1548 , što je primijećeno u historiografiji, ali i u popisu iz 1604. godine, o čemu u historiografiji nema podataka. BOA, TD 260, 323-336, 542; BOA, TD 743, 536-564.

${ }^{21}$ Bosanska riznica bila je odjeljenje glavne osmanske riznice poznate pod imenom Hizâne-i âmire, a ne nezavisna finansijska jedinica, što se jasno vidi iz finansijskih obračuna u kojima se spominju oba navedena pojma. BOA, KK.d 1981.
}

${ }^{22}$ BOA, KK.d 1981, 8. 
Navedena visina ukupnog prihoda od filurije direktni je rezultat činjenice da su u Bosni ogromne površine bile pod ovim porezom. Posljednji podaci koje imamo o tome ukazuju da je samo u Bosanskom sandžaku 1604. godine filuridžijsko stanovništvo popisano u 36 nahija Bosanskog sandžaka, od ukupno 55, kao i da je 15 nahija bilo skoro isključivo naseljeno filuridžijama. Prema određenim obračunima, radilo se o ukupno 12.324 filuridžijskih domaćinstva. ${ }^{23}$

Podaci iz navedenog katastarskog popisnog deftera iz 1604. su uočeni u historiografiji, ali nije u dovoljnoj mjeri pojašnjeno zbog čega ih je potrebno uzeti u obzir prilikom razgovora o ubiranju filurije u narednim stoljećima. Razlog za to nalazi se u činjenici da je spomenuti popis bio posljednji klasični mufassal defter, te ga je osmanska administracija upotrebljavala kao mjerodavan sve do tanzimatskih reformi. Ako uporedimo podatke iz navedenog katastarskog popisa iz 1604. godine s kasnijim defterskim izvodima (sûret-i defter), koje je osmanska administracija sastavljala krajem tridesetih godina 19. stoljeća, dolazi se do zaključka da se radilo o potpuno identičnim tekstovima, što jasno potvrđuje navedenu tvrdnju. Formalno, ovo je značilo da su iznosi filurije koji su bili zabilježeni početkom 17. stoljeća ostali na snazi vrlo dugo. ${ }^{24}$ Negdje su oni promijenjeni naknadnom administrativnom korekcijom krajem 17. i početkom 18. stoljeća, o čemu će više riječi biti u narednom poglavlju, a negdje su se stari iznosi zadržali sve do 19. stoljeća.

Gledano iz perspektive države, kada je u pitanju filurija, postojali su tokom 17. stoljeća određeni problemi u vezi sa njenim ubiranjem koji su, na koncu, utjecali na centralnu vlast da prilagođava svoju fiskalnu politiku. Osnovni problem bio je gubitak vrijednosti novca te zadržavanje starih

\footnotetext{
${ }^{23}$ S. Buzov, "Vlasi u bosanskom sandžaku i islamizacija", 109.

${ }^{24}$ Naprimjer, osmanska je administracija 1838. sastavila jedan takav izvod iz mufassal deftera, koji se odnosi na određena sela nahije Borač, u Bosanskom sandžaku. Metodom komparacije u ovom istraživanju je ustanovljeno da je njegov sadržaj isti kao i sadržaj odgovarajućeg dijela iz Opširnog popisa Bosanskog sandžaka iz 1604. počevši od imena ljudi koji se tu spominju do poreskih iznosa. Usp. Kupusović (prev.), Opširni popis Bosanskog sandžaka iz 1604. godine, 98-103; GHB, A-4773/TO.
} 
Fahd Kasumović, Rekonceptualizacija transformacijskih procesa na periferiji Osmanskog Carstva: filurija i prijelaz na režim naturalne desetine u agrarnoj ekonomiji osmanske Bosne, c. 1699-1852.

katastarskih popisa kao podloge za ubiranja podavanja. ${ }^{25}$ Kada se ove dvije stvari povežu, postaje jasno da je do kraja 17. stoljeća značaj važećih iznosa filurije u defterima opao u toj mjeri da je u stvarnosti imao osjetno nižu vrijednost nego stoljeće ranije, mada se formalno još uvijek radilo o milionima akči.

Postoje indicije da su osmanski dužnosnici postali svjesni toga još tokom 17. stoljeća, kao i da se carskim odredbama o raznim dodacima na filuriju nastojao povećati iznos koji je izvorno trebao biti ubiran, čime se, čini se, djelovalo protuinflacijski. ${ }^{26}$ Međutim, navedene mjere nisu imale trajan karakter, te su prvi ozbiljniji poduhvati na ovom polju uslijedili tek nakon Karlovačkog mira.

Drugi problem koji se za državu pojavljivao tokom 17. stoljeća je depopulacija i to što su za vrijeme ratova određene filurijske baštine ostajale puste. Posebno je ova pojava primijećena u Bosni za vrijeme Bečkog rata, a njene posljedice osjećale su se i nakon ovoga. ${ }^{27}$

Zbog svega toga, krajem 17. stoljeća, među ključnim državnim političkim akterima u Osmanskom Carstvu sve je više jačala svijest o potrebi poduzimanja određenih finansijskih mjera kako bi se riješila ekonomska kriza koja je uzdrmala državu i društvo. Donijeta je, u skladu s tim, 1691. godine odluka o reformi džizje, te je odlučeno da se ona ubuduće ubire po

${ }^{25}$ Pamuk je utvrdio da je 1584. jedan venecijanski dukat mijenjan za 65 do 70 akči. Međutim, zbog inflacije, kurs se mijenjao, pa je 1708. jedan venecijanski dukat vrijedio 360 akči. Şevket Pamuk, Ottoman Monetary History, Cambridge: Cambridge University Press, 2003, 142, 144.

${ }^{26} \mathrm{U}$ jednom popisu prihoda Bosanske riznice iz 1663. spominju se dodaci koji su bili nametnuti na filuridžijske baštine (filûriciyân bâștinelerine zamm ve ilhâk olınan zamẩim) na osnovu različitih carskih naredbi. Među njima su, navedeni ispendža, porez na sitnu stoku (adet-i agnâm), ekvivalent za vino (bedel-i hamr), pristojba na košnice (resm-i güvâre), kesr-i mîzân, gulâmiyye-i Mehmed Paşa, tefâvut-i hasene, tashîh-i sikke. Na više mjesta je bio ustanovljen dodatak džulus (pristojba naplaćivana prilikom ustoličenja vladara) koje su nametnuli osmanski sultani Mehmed III, Ahmed I, Mustafa, Osman, Murat IV, ali posebno je zanimljiv i dodatak naveden kao "svrgavanje sultana Mustafe hana" (defc-i sultân Mustafa hân). BOA, MAD.d 4718, 2.

${ }^{27}$ Osmanski dokumenti ukazuju na depopulaciju, pusta zemljišta i nemogućnost da se sakupe porezi. O ovome vidjeti dokumente u: Halil İnalcik, "Saraybosna Şer’iyye Sicillerine Göre Viyana Bozgunundan Sonraki Harb Yıllarında Bosna”, Tarih Vesikaları, sv. 2, br. 11, Ankara: Maarif Vekilliği, 1943, 375-376; BOA, D.BŞM.d 483, 1-4. 
glavi stanovnika, a ne po domaćinstvu. Rezultat toga u Bosni bilo je, između ostaloga, i to što su nemuslimanske filuridžije popisane kao obveznici džizje, o čemu se susreću podaci u popisima džizje. ${ }^{28}$ Osim toga, bio im je nametnut i porez na sitnu stoku (âdet-i agnâm). Također, 1695. u Osmanskom Carstvu je uveden doživotni sistem zakupa poreza, što je mjera koja je uskoro bila primijenjena i u Bosanskom ejaletu.

Navedeni podaci pokazuju da je krajem 17. stoljeća Bosanski ejalet prolazio kroz ekonomsku krizu, koja se dijelom može pripisati vanjskim faktorima, odnosno dugotrajnom ratovanju, koje je ostavilo traga na državne finansije, ekonomiju i živote lokalnog stanovništva. Također, krizi su doprinijeli i interni faktori, uključujući i nedovoljnu prilagođenost državnih institucija i finansijskog sistema novonastalim okolnostima, čega su brzo postali svjesni i kreatori finansijske politike. Rezultat te spoznaje bile su važne reforme koje su poduzete još u toku Bečkog rata, koje svjedoče o važnim transformacijskim procesima u državi. Međutim, krizi tu nije bio kraj, a njeno dalje rješavanje u Bosni zahtijevalo je repopulaciju opustjelih poljoprivrednih zemljišta, kao i rješavanje pitanja ubiranja državnih prihoda na filurijskim zemljištima, koja su tokom 17. stoljeća predstavljala najveći registrirani prihod državne riznice na ovom području. Rješavanje ovih problema predstavljalo je jednu od temeljnih preokupacija provincijskih vlasti u Bosanskom ejaletu na prijelazu iz 17. u 18. stoljeće.

\section{Köse Halil-pašino doba i prevođenje državnih mukata na režim naturalne desetine}

Argumentirana diskusija o procesu fiskalne transformacije u Bosanskom ejaletu zavisi od pronalaska podataka u primarnim izvorima, koji sadrže dokaze o promjenama koje su u značajnijoj mjeri utjecale na strukturu provincijskih finansija, te povezivanje više takvih promjena u jednom dužem vremenskom periodu, kako bi se stekao uvid u povijesnu dinamiku

${ }^{28}$ Vidjeti popis vlaških obveznika džizje (defter-i cizye-i Eflâkân) u kadiluku Čajniče za 1691/92. (1103. AH). BOA, MAD.d 1399, 2-19. 
i kako bi se moglo dokazati postojanje određenog transformacijskog procesa. Dosadašnji historiografski radovi u razgovoru o ovim pitanjima izostavili su fiskalne mjere koje su donijete u vrijeme kada je u Bosni namjesnik bio Köse Halil-paša (1698-1702). Ovim radom se, između ostalog, nastoji pokazati da je vrijeme Halil-pašinog namjesništva - a pogotovo period od 1699. do 1702. - izuzetno značajno za razumijevanje transformacijskih procesa u Bosanskom ejaletu, budući da je tada poduzeta opsežna akcija ukidanja filurije i paušalnih novčanih podavanja, te je niz zemljišta pod navedenim daćama preveden na režim naturalne desetine. Riječ je bila o državnim prihodima koji su bili organizirani u finansijske jedinice pod imenom mukate ( $\left.m u k a ̂ t^{c} a\right)$, koje su, zatim, obično ustupane u zakup. ${ }^{29}$ Bilo je to prvi put, nakon vremena Sulejmana Kanunija, da je država poduzela jednu širu akciju ukidanja filurije, što je dodatni razlog da se navedenom pitanju posveti posebna pažnja.

Dokazi koji upućuju na promjenu režima ubiranja državnih prihoda na mukatama u Bosanskom ejaletu susreću se ubrzo nakon Karlovačkog mira u protokolima carskih naredbi, koje su izdate radi imenovanja zakupnika i rješavanja važnih pitanja u vezi s doživotnim zakupima (ahkâm-ı beravât-ı mâlikânehâ). Naredbom iz jula 1699. bilo je finansijskim službenicima zapovijeđeno da u sumarnom katastarskom popisu (icmâl defter) naprave ispravku (tashîh) u vezi s ubiranjem prihoda na 362 baštine u nahiji Uskoplje, u Kliškom sandžaku, te da se u registar uvede obaveza plaćanja desetine umjesto dotadašnje filurije i podavanja odsjekom. Razlog za donošenje ove odluke bila je molba izvjesnog Hadži Ibrahima, koji je državni prihod na navedenim baštinama na javnoj licitaciji uzeo u doživotni zakup, uz dogovoreni uvjet da mu se omogući da na njima ubire desetinu. ${ }^{30}$

Razlog zbog kojeg je centralna vlast odlučila promijeniti režim ubiranja

\footnotetext{
${ }^{29}$ Više podataka o sistemu mukata i načinu na koji su ubirani državni prihodi vidi u: Baki Çakır, Osmanl Mukataa Sistemi (XVI-XVIII Yüzyll), Istanbul: Kitabevi, 2003, 1-256.

${ }^{30}$ Filurija je na navedenim baštinama iznosila 280 akči, dok je, prema saopćenju finansijskih službenika, uvidom u važeći katastarski defter utvrđeno da su na nekim od spomenutih zemljišnih jedinica bila registrirana paušalna podavanja $\left(\operatorname{makt}^{c}\right)$ u iznosu od 150, 140, 120, 80, 60, 50, 40 i 30 akči. BOA, MAD.d 2467, 18-19.
} 
državnih prihoda na navedenoj mukati, nalazi se u težnji vlasti da državni prihod što lakše izda u zakup, te da se na taj način dođe do novca koji je bio neophodan za pokrivanje naraslih državnih rashoda. Mobiliziranje privatnog kapitala i uspješno funkcioniranje sistema doživotnog zakupa u dobroj mjeri zavisilo je od toga da vojno-politička elita, koja je imala kapital, vidi doživotni zakup kao unosnu investiciju. Mogućnost za postizanje ovog cilja bila je značajno manja na filurijskim mukatama budući da se osnovni iznosi filurije i podavanja odsjekom, kao što je pokazano u prethodnom poglavlju, nisu promijenili od početka 17. stoljeća, uprkos ogromnoj inflaciji koja je "srozala" vrijednost akče do te mjere da je ona, na koncu, nestala iz svakodnevnog prometa. Bilo je tokom 17. stoljeća carskih naredbi kojima su bili ustanovljeni dodaci na filuriju, koji su, između ostalog, trebali nadoknaditi gubitke do kojih je inflacija dovela, no, u katastarskim defterima, kao zvaničnim registrima, ostao je na snazi stari iznos. ${ }^{31}$ Desetina je, s druge strane, predstavljala naturalno davanje, a poljoprivredni proizvodi su se mogli prodati na tržištu, što je bila atraktivnija mogućnost za zakupce. Zbog toga, spomenuti je zakupac dogovorio s vlašću promjenu režima ubiranja prihoda, a tokom 18. stoljeća brojni su drugi zakupci dogovorili slične aranžmane, te su neki u korespondenciji s vlastima otvoreno isticali da im je otkazivanje desetine, kao i težnje pojedinaca da se ponovo uvede filurija, stvaralo gubitke. ${ }^{32}$

Navedeni dokument iz 1699. pokazatelj je da je potreba uspostavljanja funkcionalnog sistema zakupa poreza motivirala centralnu vlast da pristupi akciji ukidanja filurije, ali za sada se ne može sa sigurnošću reći kada se desio prvi slučaj ove vrste. Moguće je da je takvih slučajeva bilo i ranije, pogotovo nakon 1695. godine, kada je ustanovljen doživotni zakup u Osmanskom Carstvu, ali, isto tako, podaci s kojima trenutno raspolažemo jasno pokazuju da je intenziviranje državnih napora na ovom polju moglo

${ }^{31}$ BOA, MAD.d 4718, 2.

${ }^{32}$ Zakupnik "Mukate hercegovačkih vojnuka" (mukâta-yı voynugân-ı Hersek) žalio se 1776. centralnoj vlasti na pojedine osobe koje su odbile plaćati desetinu, pri čemu je tvrdio da su navedeni, na neki način, uspjeli čak isposlovati i ferman o vraćanju filurije. Ova molba vlastima sadržavala je veoma važnu izjavu zakupnika da je navedena situacija dovela do manjka prihoda na mukati (mukâtcanun kesr ve noksânına bâ?is ve bâdî olmagla). BOA, C.ML 14885. 
doći tek nakon što su se ratne okolnosti okončale.

Koliko god bio značajan spomenuti dokument, s obzirom na ciljeve ovog rada, ipak, on samostalno ne daje mogućnost da se nešto više kaže o razmjerima osmanske aktivnosti na ukidanju filurije u Bosanskom ejaletu na prijelazu iz 17. u 18. stoljeće, te je za stjecanje uvida u ovu problematiku potrebno uzeti u obzir i druge dostupne arhivske izvore.

Nekoliko dokumenata iz nešto kasnijeg vremena upućuje na zaključak da se radilo o akciji vlasti koja je zahvatila veći broj zemljišnih jedinica i veći broj mukata. Zakupac državnih prihoda na "Mukati hercegovačkih vojnuka" (mukâtaca-yı voynugân-ı Hersek), koja je za predmet imala ubiranje podavanja nad nekadašnjim vojničkim zemljištima, u dopisu vlastima iz 1776. godine, tvrdio je da je u 1700/01. (1112. AH), u Halil-pašino doba, "većina mukata" (ekseriyâ mukâtacâtı) u Bosanskom ejaletu bila prevedena s filurije na desetinu. ${ }^{33}$

Navedeni podatak nije precizan i ne možemo sa sigurnošću utvrditi o kojem se broju radilo. Međutim, potvrde za neke pojedinačne mukate moguće je naći. Naprimjer, sačuvan je prijepis fermana iz 1723. koji potvrđuje da je "Mukata hercegovačkih vojnuka" bila prevedena početkom 18. stoljeća na režim desetine te su to dužnosnici centralne vlasti uzeli u obzir prilikom rješavanja navedenog spora. ${ }^{34}$

Osim toga, sačuvani su i podaci u izvorima da se akcija pretvaranja filurijskih mukata u desetinske nastavila i slijedeće 1701/02. (1113. AH), ali i u kasnijem razdoblju. Podaci o ovome mogu se pronaći za filuridžije u nahiji Drežnica, u Hercegovačkom sandžaku, koji su bili u sastavu mukate Goranci. ${ }^{35}$ Navedena mukata $\mathrm{u}$ to vrijeme nije izdavana u zakup, već su njen prihod direktno sakupljali posadnici mostarske tvrđave, koji su se od

${ }^{33}$ BOA, C.ML 14885.

${ }^{34}$ BOA, C.ML 14885.

${ }^{35} \mathrm{U}$ jednom dokumentu iz 1784. (1198. AH) se navodi da je na njihovim baštinama 1113. godine ukinuta filurija, "prema Halil-pašinom uređenju”, kao i da je ista "pretvorena" u naturalnu desetinu ("resm-i filûrîleri yüz on üç senesi Bosna vâlisi esbek müteveffâ Halîl Paşa nîzâmı üzere refc ve aynî öşre tebdîl”); "resm-i filûrîlerı refc ve mâlları sẩir mukâtacât misillü öşr-i şercîden tahsîl olınmak üzere”. BOA, C.ML 30261. 
tog prihoda i finansirali. Glavni osmanski defterdar je zabilježio u svom izvještaju velikom veziru da je na njoj bila "ukinuta filurija te da se, kao i na drugim mukatama, (podvukao F. K.) njen prihod sakuplja od desetine". ${ }^{36}$

Navedeni podaci upućuju na zaključak da se promjena režima ubiranja državnih prihoda koja je izvršena u Bosni na prijelazu iz 17. u 18. stoljeće nije odnosila na jednu ili nekoliko mukata, nego da se radilo o opsežnoj akciji, koja se odnosila na veći broj državnih mukata. Zanimljivo je da se u nekim osmanskim dokumentima ova vrsta akcije označava izrazom "Halil-pašino uređenje/poredak" (Halîl Paşa nîzâmı), što ukazuje na to da je osmanska finansijska administracija kasnijeg doba smatrala da je Halilpaša imao značajnu ulogu u reorganizaciji sistema mukata i u s tim povezanim finansijskim mjerama, uključujući i ukidanje filurije. Međutim, ne bi trebalo misliti da se takvo što moglo izvesti bez suglasnosti i suradnje centralne vlasti. Zapravo, poduhvat ovih razmjera jedino je bilo moguće postići na taj način. Znamo da su odluke o izdavanju u doživotni zakup bile ingerencija centralne vlasti, dok su namjesnici vodili računa o tome da se red i zakon poštuje, prihod ubire, pusta zemljišta nasele, te su naređivali sastavljanje popisa prihoda od mukata i slično.

Napori vlasti, kako centralnih tako i provincijskih, na reorganiziranju filurijskih mukata u Bosanskom ejaletu početkom 18. stoljeća bili su uspješni, te se u popisima mukata susreću, između ostalog i "mukate vlaških poreza" (mukâtaca-yı rüsûm-ı Eflâkân), što ukazuje na to da je vlast uspješno pronašla zakupce, koji su bili zainteresirani za ulaganje kapitala u poduhvat zakupljivanja državnih prihoda. Naprimjer, u jednom popisu bosanskih mukata, iz perioda u kojem je namjesnik bio Halil-paša, spominje

${ }^{36} \mathrm{U}$ jednom fermanu iz 1709. se navodi da je prihod Mukate Goranci u Halil-pašino vrijeme bio namijenjen za plate (odžakluk) posadnika mostarske tvrđave, kao i da su oni u to vrijeme upravljali ovom mukatom (neferât-ı mezkûre taraflarından zabt olınmak şartıyla). Na osnovu dokumenta se vidi da su oni sami tražili podavanja od stanovništva te da su se žalili vlasti ako bi bilo odbijanja da se plati. Budući da se ovdje nije radilo o zakupničkom odnosu, ne govorim u ovom slučaju o mukati kao o zakupnoj jedinici, nego samo kao o skupu državnih prihoda, koji su bili sakupljani na opisani način. Tek u kasnijem periodu ovom su mukatom upravljali doživotni zakupnici, a ne sami posadnici, što se vidi iz dokumenata koji se nalaze pod istom signaturom. BOA, C. ML 30261. 
se čak 17 mukata vlaških poreza, s ukupnom godišnjom zakupninom od 6.347.984 akči. ${ }^{37}$ Među njima nije, iz nekog razloga, bila navedena mukata vlaških poreza nahije Uskoplje, mada je ranije dokazano da je 1699. i ona funkcionirala, odnosno da je tada prevedena na režim desetine. Također, znamo da je 1711/12. njena godišnja zakupnina iznosila 171.500 akči, pa se zajedno s njom broj poznatih mukata vlaških poreza iz ovog vremena penje na 18. Osmanski uspjeh u izdavanju ovih mukata u zakup treba pripisati jednim dijelom i odluci da se dio tih mukata prevede na desetinu. Međutim, zanimljivo je da su sve mukate vlaških poreza, ${ }^{38}$ kako one koje su prevedene na desetinu, tako i one koje su ostale na režimu filurije, i dalje bile administrativno vođene kao "mukate vlaških poreza", što ne znači nužno da je na njima ubiran vlaški porez, nego da ih je država nastavila tako zvati slijedeći finansijske prakse iz prethodnog doba.

Kada se sve navedeno uporedi s podacima koji se susreću u historiografiji, dolazi se do zaključka da Halil-pašino doba nije samo značajno zbog toga što je u njemu završen Bečki rat i sklopljen Karlovački mirovni ugovor. Gledano s ekonomske strane, to je vrijeme važno shvatiti radi razumijevanja transformacijskih procesa, budući da je u njemu više zakupnih jedinica u Bosanskom ejaletu bilo prevedeno s filurije i podavanja odsjekom na režim naturalne desetine. Argumenti donijeti u ovom poglavlju dokazuju tezu da prijelaz na režim desetine u Bosanskom ejaletu treba razumijevati kao proces koji ima mnogo dublje korijene od tanzimatskih reformi, te da se jedna od najvažnijih faza u tom procesu odigrala u prvim godinama nakon Karlovačkog mira, kada se na namjesničkoj stolici u Bosni nalazio Köse Halil-paša, dok je 19. stoljeće samo vrijeme kada se ovaj proces okončao.

\footnotetext{
${ }^{37}$ Važno je naglasiti da sve ove mukate nisu bile sastavljene isključivo od filurije ili desetine koja je zamijenila filuriju, nego da se u okviru njih susreću i neki drugi državni prihodi.

${ }^{38}$ BOA, D.BŞM.BNH.d 16771, 2-9. Osim ovoga, treba istaći da su sačuvani i popisi mukata iz Halilpašinog vremena u kojima se navodi da je on dao da se te mukate popišu (ber-muceb-i tahrîr-i hazret-i vezir-i mükerrem Halîl Paşa). BOA, MAD.d 16064, 7.
} 


\section{Strukturalne promjene u osmanskim finansijama i njihove socijalno-ekonomske posljedice}

Donošenje zaključaka o značaju određenih finansijskih mjera u ekonomskoj povijesti Osmanskog Carstva, odnosno povijesti neke od regija koje su se nalazile u njegovom sastavu, zadatak je koji zavisi od utvrđivanja kratkoročnih i dugoročnih posljedica, koje su te mjere proizvele na polju finansija, te o utjecaju koji su one imale na život lokalnog stanovništva. U tom smislu, kada je riječ o posljedicama osmanske akcije ukidanja vlaških poreza i prevođenju državnih zakupnih jedinica na režim naturalne desetine, koja se, kao što je pokazano u prethodnom poglavlju, odigrala na prijelazu iz 17. u 18. stoljeće, od ključnog je značaja pružiti odgovor na sljedeća pitanja: Na koji način se ova mjera odrazila na provincijske finansije? Koliko je ona doprinijela funkcioniranju vlasti i vojnog aparata u Bosanskom ejaletu? Kako se odrazila na vojno-administrativnu elitu i slojeve raje? Da li je moguće govoriti o značajnim posljedicama za tržišnu razmjenu u Bosanskom ejaletu? Radi stjecanja uvida u navedena pitanja bit će analizirani podaci iz Halil-pašinog vremena, kao i odgovarajući podaci iz arhivskog materijala koji je nastao u različitim decenijama 18, te u prvoj polovici 19. stoljeća.

Osnovna teza koja se zagovara u ovom poglavlju jeste da osmansku akciju ukidanja novčanih podavanja i njihovo mijenjanje naturalnom desetinom u Bosanskom ejaletu, krajem 17. i početkom 18. stoljeća, treba razumijevati kao strukturalnu promjenu u provincijskim finansijama navedenog područja. Zanimljivo je da je u historiografiji vrlo malo prostora posvećeno provincijskim finansijama Bosanskog ejaleta, a i oni podaci koji postoje o ovome pitanju ne spominju pojam strukturalna promjena. ${ }^{39}$ Ovim radom se predlaže da je upravo to pravi naziv za opisivanje onoga što se desilo u provincijskim finansijama Bosne u Halil-pašino doba. Oznaka

\footnotetext{
${ }^{39}$ Rijetki su radovi koji govore o fenomenu strukturalnih promjena na širem polju osmanistike. Jedan od njih je slijedeći: Yavuz Cezar, "From Financial Crisis to Structural Change: The Case of the Ottoman Empire in the Eighteenth Century", u: Oriente Moderno, Nuova serie, sv. 18 (79), br. 1, Rim: Istituto per l'Oriente C. A. Nallino, 1999, 49-54.
} 
strukturalna promjena u ekonomskoj se literaturi, inače, koristi kao oznaka za različite krupne promjene na temeljnim poljima ekonomije, a kada se upotrijebi u finansijama, onda se pod tim podrazumijeva bilo koja značajnija izmjena strukture državnih prihoda i rashoda. Ranije spomenuti podatak da je u Bosni u Halil-pašino doba "većina mukata" ${ }^{20}$ prevedena na desetinu, $\mathrm{u}$ kombinaciji s konkretnim primjerima mukata, koje su prevedene s filurije na desetinu, indikator su postojanja takve krupne promjene u strukturi državnih prihoda. Dodatno, značaj ove mjere još je veći kada se ima u vidu podatak da filurija tada nije predstavljala bilo kakav prihod nego, finansijski gledano, jedan od najvažnijih poreza u Bosanskom ejaletu. ${ }^{41}$

Prema tome, strukturalna promjena o kojoj se ovdje govori predstavljala je promjenu u izvorima državnih prihoda koji su prodavani u zakup, a ne mijenjanje onoga što je direktno ulazilo u državnu riznicu. Postojanje sistema zakupljivanja poreza značilo je da je, bez obzira na to da li je na terenu bilo ubirano naturalno ili novčano podavanje, u državnu riznicu ulazio isključivo novac, što je bio rezultat činjenice da država svoj prihod nije ubirala direktno, nego ga je prodavala u zakup, obično doživotni. Državni su zakupnici poreza, u ovom sistemu, državi plaćali unaprijed određeni dio na ime zakupnine ( $m u^{c}$ acelle). Redovnu godišnju zakupninu mogli su ispunjavati tako što su novac predavali direktno osobama koje je država finansirala od mukate, dok je dio mogao biti u gotovini prosljeđivan državnoj blagajni. Naprimjer, zakupac mukate vlaških poreza nahije Uskoplje, koja je 1699. bila prevedena na režim desetine, osim unaprijed plaćene zakupnine, obavezao se da će godišnje predavati novac posadnicima tvrđave Bihać, kao i da će pod imenom irsâliye slati određeni iznos provincijskoj Bosanskoj riznici (Bosna hazînesi), kao odjeljenju Glavne državne riznice. ${ }^{42}$

\footnotetext{
${ }^{40}$ Riječ je, po svemu sudeći, o nekom većem broju mukata, ali ne može se znati konkretan broj, niti za sada znamo omjer mukata koje su prevedene na desetinu, u odnosu na one koje su zadržale filuriju. BOA, C.ML 14885.

${ }^{41}$ Obračun prihoda i rashoda Bosanskog ejaleta iz 1679. ovo odlično ilustrira. Filurija je u njemu 1znosila 43.43\% ukupnih prihoda te je činila najveću pojedinačnu stavku. BOA, KK.d 1981, 8.

${ }^{42}$ BOA, MAD.d 2467, 18-19.
} 
Navedena strukturalna promjena u provincijskim finansijama Bosanskog ejaleta pitanje je koje ne treba promatrati isključivo iz perspektive vlasti, odnosno iz pozicije državnih institucija. Ne treba zaboraviti da se ona itekako osjetila u životima različitih slojeva stanovništva, te je upravo identificiranje posljedica koje je ona proizvela u svakodnevnom životu, ključno za donošenje zaključaka o povijesnom značaju navedene finansijske reforme.

Zakupnici su bili direktno zainteresirani za prevođenje filurijskih mukata na režim desetine, budući da su u tome vidjeli priliku za zaradu. $\mathrm{Na}$ osnovu podataka iz osmanskih izvora može se zaključiti da se radilo uglavnom o pripadnicima društvenih elita, koje su bile vlasnici kapitala, što se vidi iz titula koje su stajale pored imena ovih zakupaca. Naprimjer, kao zakupce nekih od ovih mukata susreću se osobe pored čijeg imena je stajala titula aga, ${ }^{43}$ efendija ${ }^{44}$ drugdje je to bila titula beg, ${ }^{45}$ a moguće je bilo susresti i paše. ${ }^{46}$ Sistem zakupljivanja bio je dizajniran tako da se nije ograničavao na lokalne ljude nego na vlasnike kapitala u širem osmanskom kontekstu, te tako na nekim filurijskim mukatama u Bosni koje su bile prevedene na režim desetine u izvorima pronalazimo i visoke državne dužnosnike iz provincija koje su bile udaljene od Bosne, kao što je, naprimjer, bila Anadolija. ${ }^{47}$

Osobe koje su bile zainteresirane da filurijske mukate koje su prevedene na desetinu budu operativne, bili su i svi oni čija je egzistencija direktno zavisila od navedenih mukata. Koliko se može vidjeti iz državnih popisa mukata i s njima povezane arhivske građe, najbrojnija skupina ovih osoba

\footnotetext{
${ }^{43}$ Mukatu hercegovačkih vojnuka, koja je 1700/01. prevedena na režim desetine, držali su kao zakupnici 1787. Ali-aga i Ahmed-aga. BOA, C.ML 23446.

${ }^{44}$ Među zakupcima mukate Goranci spomenut je 1784. (1198. AH) izvjesni Mustafa-efendija, koji je zajedno sa nekoliko partnera držao ovu mukatu u doživotnom zakupu. Na osnovu dostupnih podataka, znamo da je ova filurijska mukata bila prevedena na režim desetine 1701/02. (1113. AH). BOA, C.ML 30261.

${ }^{45}$ Mukatu vlaških poreza Uskoplja, koja je 1699. prevedena na režim desetine, držao je 1730/31. (1143. AH) u doživotnom zakupu Hasan-beg, sin bosanskog vezira Ahmed-paše. BOA, MAD.d $10172,37$.

${ }^{46}$ BOA, C.ML 14885.

${ }^{47}$ Mukatu hercegovačkih vojnuka držao je 1776. u zakupu anadolski valija Abdullah-paša. BOA, C.ML 14885.
} 
bili su posadnici različitih tvrđava. Naprimjer, u jednom popisu mukata Bosanskog ejaleta, koji je napravljen 1729/30. (1142. AH), u doba namjesnika Osman-paše, sve zabilježene mukate koje su bile operativne imale su pored sebe i zabilješku da je njihov prihod bio namijenjen za neku od tvrđava, dok se ponegdje susreću i manji iznosi koji su bili namijenjeni i za pojedine džamijske službenike. ${ }^{48}$ Mada u ovom popisu nisu razdvojene filurijske mukate koje su bile prevedene na režim desetine u odnosu na one na kojima je zadržan stari režim ubiranja prihoda, jasno je da je osmanska politika prevođenja filurijskih mukata na desetinu i njihovo izdavanje u doživotni zakup, u konačnici, bilo usmjereno za pokrivanje troškova vojske i ulemanskog sloja, te da se ona odražavala na njihov životni standard.

Direktne posljedice odluke osmanskih vlasti da promijene režim ubiranja prihoda na velikom broju mukata u Bosanskom ejaletu, po svemu sudeći, najviše su osjetili upravo oni koji su trebali plaćati taj prihod, a to su bili svi oni koji su u svojim rukama držali zemljišne tapije na filurijskim baštinama. Radilo se tu o pripadnicima sloja raje, kao i o pripadnicima vojničke klase koji su došli u posjed rajinskih baština, te su, stoga, bili dužni plaćati i podavanja koja su padala na tu zemlju. ${ }^{49}$

Za posjednike zemljišnih tapija prijelaz na naturalnu rentu značio je povećanje ekonomskog nivoa tereta koji je trebalo podnijeti. Naime, filurija i podavanja određena odsjekom su zbog velike inflacije i činjenice da se nisu mijenjali još od početka 17. stoljeća za posjednike zemlje predstavljali manju obavezu u odnosu na procentualno davanje dijela ljetine koju je predviđao

${ }^{48}$ BOA, D.BŞM.BNH.d 16777, 1-7.

${ }^{49}$ Raja je tradicionalno držala baštine pod filurijom, a to se nastavilo i u 18. stoljeću. Na to upućuju, između ostalog, tvrdnje nekoliko nemuslimana, prilikom jedne žalbe centralnoj vlasti, da su od drugih nemuslimana (zimmî) kupili "stare baštine" na koje se plaćala filurija (BOA, A.DVNS. AHK.BNH.d 1, 192). Također, u ovom periodu susreću se i brojne čifluk sahibije iz reda vojničke klase kao posjednici zemlje. Naprimjer, u jednom osmanskom registru, u kojem su bili ubilježeni posjednici filurijskih baština na Kobaškoj mukati, pored imena nekih posjednika stajale su titule aga, beg i efendija. Navedeno ukazuje da se radilo o čifluk sahibijama iz reda vojničke klase (GHB-4855/TO-30). Ovi primjeri ne govore o baštinama koje su prevedene na filuriju, nego o onima na kojima je bio zadržan ovaj porez. Međutim, važni su, jer je izvjesno da je o sličnoj strukturi posjednika zemlje moguće govoriti i na mukatama koje su bile prevedene na desetinu. 
sistem desetine. Nijedno ni drugo nisu bile neizdržive obaveze, ali je činjenica da je procentualna desetina u datim okolnostima predstavlja težu daću. Dobar pokazatelj toga da je nametanje desetine bilo teža obaveza su i brojni dokumenti koji svjedoče o pokušajima određenih osoba koje su držale filurijske baštine da se zadrži stari sistem ubiranja podavanja, a ne desetina. ${ }^{50}$

Mada se u mnogim izvorima govori samo da je zavedena desetina, postavlja se pitanje da li je prijelaz na režim desetine nosio sa sobom i neke druge daće, kao što je to bilo u 16. stoljeću, kada je vlaškim skupinama ukinuta filurija u vrijeme Sulejmana Zakonodavca. Naime, tada su im bile nametnute i određene prateće novčane daće koje su bile karakteristične za zemljoradničku raju. ${ }^{51}$

Postoje dokazi da je to bio slučaj i u Bosanskom ejaletu u 18. stoljeću. $\mathrm{Na}$ takav zaključak upućuje molba jednog osmanskog zakupnika Mukate hercegovačkih vojnuka u kojoj je bilo izričito navedeno da su na spomenutoj mukati od vremena kada je prevedena s filurije i podavanja odsjekom na desetinu, u Halil-pašino vrijeme, ubirani redovno desetina, kao i "ostale daće" (rüsûmat-ı sẫire). Mada u molbi nije precizirano o kakvim se daćama radilo, u jednom drugom dokumentu koji je dat na margini spominju se još ubiranje tapijske pristojbe (resm-i tapu), mlađarine (resm-i arûs), pristojbe na mlin (resm-i âsiyâb), badihava (bâd-u hevâ), kao i porez na sitnu stoku (resm-i âdet-i agnâm). ${ }^{52} \mathrm{Na}$ nekim drugim baštinama u Hercegovačkom sandžaku, koje su bile prevedene na režim desetine, osim ove naturalne daće spominju se još i resm-i čift (resm-i çift) i ispendža (ispence).$^{53} \mathrm{Ne}$ može se sa sigurnošću potvrditi da je ista stvar vrijedila za svaku baštinu koja je u Bosni bila prevedena na režim desetine, ali je izvjesno da treba ozbiljno uzeti u obzir i mogućnost plaćanja navedenih novčanih daća, kao i ostalih klasičnih zemljoradničkih podavanja.

${ }^{50} \mathrm{O}$ tome svjedoči ranije navedeni primjer Mukate hercegovačkih vojnuka. BOA, C.ML 14885.

${ }^{51} \mathrm{O}$ tome svjedoči, između ostalog, mufassal defter Bosanskog sandžaka iz 1528-30. BOA, TD 157.

${ }^{52}$ BOA, C.ML 14885.

${ }^{53}$ Resm-i čift i ispendža se spominju kao daće 1709. (1121. AH) na mukati Goranci, u Hercegovačkom sandžaku, koja je nekoliko godina ranije bila prevedena na režim desetine. Raja je tada odbijala da ih plati, kao i novouvedenu desetinu. BOA, C.ML 30261. 
Formalno, navedene daće trebali su plaćati oni koji su držali tapiju. Međutim, kada su bile u pitanju osobe iz vojničkog sloja, koje su na neki način došle do tapije te su postale čifluk sahibije, izvjesno je da su oni svoje obaveze ove vrste prebacivali na raju, koja je bila nastanjena na datim baštinama, odnosno na osobe koje su bile u poziciji čif̌̌ija na navedenim zemljišnim parcelama. ${ }^{54}$

Da bi se odgovorilo na sva pitanja koja su postavljena u uvodu ovog poglavlja, potrebno je još osvrnuti se i na ispitivanje mogućnosti koju je strukturalna promjena $\mathrm{u}$ finansijama $\mathrm{u}$ vidu ukidanja vlaških poreza i širenju naturalne desetine imala na ekonomske prilike u ovoj osmanskoj provinciji.

Za sada nema nekih pokazatelja koji bi dali čvrste brojčane parametre o utjecaju ove mjere na ekonomsku razmjenu u Bosni. Međutim, izvjesno je da su se morale desiti krupne promjene na tržištu navedene provincije. Ekonomska logika u ovom slučaju upućuje na takav zaključak. Naime, osoba koja je dužna plaćati novčani porez, filuriju i podavanja odsjekom, treba izaći na tržište i prodati svoju robu, kako bi na taj način došla do novca za ispunjavanje poreske obaveze. Kada se takvoj osobi promijeni režim ubiranja prihoda, odnosno kada se umjesto novčane filurije zavede obaveza plaćanja naturalne desetine, onda ta osoba ne mora izlaziti na tržište da bi ispunila svoju obavezu prema državi, već je dovoljno da državnim sakupljačima poreza ili zakupnicima preda jedan dio ljetine. Navedena pojava ne znači potpuno zatvaranje ekonomskog sistema na mikrorazini, ali se čini opravdanim zaključiti da mjere ovog tipa, kao ni ostali slični metodi ubiranja naturalnih poreza i rente, ne potiču razvoj trgovinske razmjene, nego, štaviše, doprinose njenom smanjivanju. Budući da imamo podatke koji upućuju na to da je na većem broj mukata u Bosni došlo do navedene

${ }^{54}$ Ovdje bi se mogla napraviti paralela sa raširenom praksom čifluk sahibija da na raju prebacuju obavezu plaćanja filurije koja je spadala na njihove čifluke. Naprimjer, čifluk sahibija Omer Đumišić tvrdio je, u 18. stoljeću, da je držao neke baštine kao svoj čifluk, te da je nadležni timarnik od tamošnje raje (tj. čifčija) tražio filuriju za ove baštine (GHB, A-4855/TO-32). Ako se zna da su prebacivanje podavanja na raju prakticirale čifluk sahibije na zemlji na kojoj su poreze sakupljali timarnici, izvjesno je da su slično postupali i čifluk sahibije u njihovom bliskom susjedstvu, na zemlji na kojoj su poreze sakupljali zakupnici, bilo da se radilo o filuriji ili desetini. 
promjene, kao što je to ranije pokazano, jasno je da je to moralo u većoj mjeri djelovati i na tržište poljoprivrednih proizvoda.

Kada se sve navedeno uzme u obzir, dolazi se do zaključka da je osmanska politička odluka da se promijeni režim ubiranja državnih prihoda na velikom broju mukata u Bosni krajem 17. i početkom 18. stoljeća predstavlja dio jedne stabilizacijske politike, te da je ona imala za cilj primarno fiskalni rezultat. Na ovaj način se željelo stvoriti povoljnije ekonomsko okruženje za zakupce poreza, te se tako namjeravala postići bolja pokrivenost državnih rashoda. Na tom polju se navedena politika može smatrati efikasnom, jer je ovaj cilj bio i postignut. Strukturalna promjena koja se desila u provincijskim finansijama odrazila se na živote vojnog aparata, ulemanski sloj, zakupnike poreza, kao i na sve one koji su u svojim rukama držali zemlju podložnu ubiranju poreza, a to je uključivalo raju, kao i pripadnike vojničke klase koji su na neki način došli do posjeda nad nekadašnjim vlaškim baštinama. Za razliku od finansija, gdje je ova mjera imala pozitivan efekat, ona se negativno odrazila na širem ekonomskom polju, budući da je djelovala destimulirajuće na obim robno-novčane razmjene na tržištu poljoprivrednih proizvoda u Bosanskom ejaletu.

\section{Otpori promjenama i pokušaji vraćanja na staro stanje}

Osmanski transformacijski procesi i finansijske reforme koje su tokom višestoljetnog postojanja Osmanske države poduzimane, često nisu tekle glatko, te primarni izvori pokazuju da je vlast na raznim stranama bila prinuđena reagirati zbog različitih izazova koju su pred nju postavljali sultanovi podanici, što je, između ostalog, uključivalo i njihovo izbjegavanje da ispoštuju državne norme u vezi s plaćanjem podavanja. Dokumenti daju snažnu osnovu za zaključak da navedena tvrdnja važi i za baštine u Bosanskom ejaletu koje su na prijelazu iz 17. u 18. stoljeće bile prevedene na režim naturalne desetine, kao i da je promjena koja se desila, naišla na otpor lokalnog stanovništva koji se manifestirao u odbijanju plaćanja desetine, te pokušaju da se vrati stari režim ubiranja državnih prihoda. Razlozi 
koji su doveli do otpora provedenim finansijskim reformama, kao i način na koji se osmanska vlast borila s ovim izazovima od izuzetnog su značaja za razumijevanje uspješnosti državnih institucija u implementaciji reda i zakona u navedenoj pograničnoj provinciji u vremenu koje je poznato kao doba krize i transformacije. Zaključci koji će biti donijeti bazirat će se na analizi finansijskih dokumenata, koji se odnose na dvije mukate s područja Hercegovačkog sandžaka, koje su u Halil-pašino doba bile prevedene na naturalnu desetinu - Mukati hercegovačkih vojnuka i Mukati Goranci.

Dokazi o odbijanju posjednika nekadašnjih filurijskih baština da plate desetinu, kao i ostala novčana podavanja, koja su im bila nametnuta krajem 17. i početkom 18. stoljeću, susreću se u osmanskim izvorima ubrzo nakon Halil-pašinog vremena, ali i više decenija nakon toga, što daje osnovu za zaključak da se nije radilo o jednokratnom problemu, nego o pojavi s kojom se osmanska vlast dugo borila. Na mukati Goranci, koja je između ostalog obuhvaćala i sela nahije Drežnica, takva je pojava primijećena još 1709 , što se vidi iz jednog carskog fermana, a isti problem pojavio se $\mathrm{i}$ $1784 .{ }^{55} \mathrm{Na}$ Mukati hercegovačkih vojnuka (mukâtaca-yı voynugân-ı Hersek), koja se nalazila u istočnim predjelima Hercegovačkog sandžaka, uključujući i sela oko Foče i Nevesinja, kao i Olovo, ovaj problem se susreće 1723. te, kasnije, 1776. i $1787 .{ }^{56}$

Razlog za odbijanje ispunjavanja obaveze plaćanja desetine i novčanih daća prema zakupnicima i tvrđavskim posadnicima, ${ }^{57}$ imao je jasno ekonomsko utemeljenje. Novi režim podavanja bio je nepovoljniji za posjednike nekadašnjih filurijskih baština. Dok je on, iz perspektive vlasti, imao pozitivan finansijski efekt, za lokalno stanovništvo je značio veće opterećenje, te u tome treba tražiti glavni razlog za odbijanje plaćanja.

${ }^{55}$ BOA, C.ML 30261.

${ }^{56} \mathrm{Za}$ one koji su 1723. odbijali plaćanje bilo je u carskom fermanu iz te godine navedeno da su se "inatili i suprotstavljali" (inâd ve muhâlefet idenleri), kao i da su postupali suprotno defterima, te da su odbijali desetinu (defterlere mugâyır hareket ve össr virilmekden ib $\hat{a}^{\circ}$ ). BOA, C.ML 14885.

${ }^{57}$ Mukatu Goranci držali su direktno 1709. posadnici tvrđave Mostar (serbestiyet üzere neferât-ı mezbûr taraflarından zabt olınmak şartıyla). Za razliku od toga, 1784. bila je u doživotnom zakupu više osoba (ber-vech-i mâlıkâne uhdelerinde oldiğı). BOA, C.ML 30261. 
Dokumenti koji su sačuvani o ovom pitanju ne daju osnovu za zaključak da se odbijanjem plaćanja poreza namjeravalo upotpunosti odbaciti osmansku vlast i poreski sistem, nego prije da se radilo o pokušajima da se isposluje vraćanje starog režima podavanja, koji je bio u finansijskom pogledu povoljniji za posjednike baština. Argument koji bi išao u korist ove teze je tvrdnja jednog od zakupaca iz 1776. da su određene osobe na Mukati hercegovačkih vojnuka, prije nego što su odbile plaćanje desetine, isposlovale ferman u Carigradu da trebaju u skladu sa starim upisima u defteru plaćati filuriju. Očito je da se nastojalo u ovom slučaju vratiti na stari režim podavanja. Međutim, nije jasno kako je, uopće, došlo do toga da se izda ferman ovog sadržaja. Zakupac je smatrao da se radilo o "varci” (hîle), kao i da su osobe koje su odbijale plaćanje "smutljivci" (müfsid). Žalio se na njihovo postupanje, a vlast mu je izašla u susrest potvrdivši mu pravo da ubire desetinu i prateća podavanja..$^{58}$

No, nisu svaki put posjednici nekadašnjih filurijskih baština tražili legitimno rješenje u Carigradu, već su jednostavno odbili platiti pozivajući se na ono što je ubilježeno u defterima, što, također, treba shvatiti kao intenciju da se vrati stari režim podavanja. Naprimjer, stanovnici Drežnice su tvrdili da je njihova zemlja "sokolarska i jastrebarska zemlja" (şâhinci ve toğancı arâzisi), te da oni ne trebaju plaćati desetinu. Međutim, glavni šef osmanskih finansija u Carigradu nije im dao za pravo, te je preporučio velikom veziru da oni plaćaju desetinu. ${ }^{59}$

Identitet osoba koje su odbijale platiti desetinu nije dovoljno jasan mada se susreću u izvorima neki važni pokazatelji koji mogu pomoći u razumijevanju navedenog pitanja. Naprimjer, u nekim od spomenutih dokumenata govori se o raji koja se suprotstavljala ubiranju desetine, bez spominjanja bilo kakvih imena. ${ }^{60}$ Ovaj podatak je značajan, jer pokazuje kojem su socijalnom

${ }^{58}$ BOA, C.ML 14885.

${ }^{59}$ BOA, C.ML 30261.

${ }^{60}$ Prema izvještaju glavnog osmanskog defterdara iz 1787. (1201. AH), na Mukati Završje, koja je pripadala Mukati hercegovačkih vojnuka, neka je "seoska raja" (kurâ recâââları) to odbijala, te su umjesto toga htjeli plaćati filuriju (öşre bedel resm-i filûrî virmek içün). Ranije je ova finansijska jedinica bila prevedena na desetinu. BOA, C.ML 23446. 
sloju pripadale osobe koje su se bunile, bar u spomenutim slučajevima. Drugdje je to još neodređenije, pa se umjesto rajinskog sloja jednostavno govori o nekim seoskim stanovnicima (kurâ ehâlilerinden bazıları) ${ }^{61}$ ili pak osobama koje su bili zlonamjerne (ahsâb-ı agraz) i smutljivci (müfsid ve müzevvir). ${ }^{62}$

Reakcija centralne vlasti u svim navedenim slučajevima išla je u korist zakupnika, odnosno u korist tvrđavskih posadnika, tamo gdje su oni direktno upravljali mukatom. Obrazloženje koje je ponuđeno u jednom od navedenih dokumenata najbolje govori čime se to vodila vlast: "potrebno je štititi i čuvati ovakve prihode državnih mukata od situacija koje dovode do gubitaka i štete". ${ }^{63} \mathrm{Na}$ drugom mjestu, otvoreno je bilo navedeno da je upravo odbijanja plaćanja desetine i ostalih podavanja na mukatama dovodilo do gubitka državnog prihoda. ${ }^{64}$

$\mathrm{Na}$ osnovu svega navedenog, vidi se da se tokom 18. stoljeća centralna vlast na području Bosanskog ejaleta susretala s poreznom evazijom, odnosno s pokušajima lokalnih posjednika nekadašnjih filurijskih baština da izbjegnu plaćanje desetine i novčane daće, koje su uvedene početkom 18. stoljeća, te da se željelo nastaviti plaćati porez prema starim registrima. Bio je to značajan izazov za državu budući da je dovodio u pitanje finansijsku opstojnost mukata, kao što je ugrožavao i službe koje su finansirane iz navedenih mukata. Ne može se reći da je vlast ikada trajno uspjela riješiti ovaj problem, jer su se osporavanja državnih propisa ponavljala, kao što je teško reći da ijedna država može upotpunosti eliminirati poreznu evaziju. Međutim, dokumenti navedeni u ovom poglavlju pokazuju da je vlast bila vođena fiskalističkim rezonom, te da je borba s poreznom evazijom bila dio aktivne političke strategije, o čemu je vodila računa centralna vlast, kao i ključni akteri u provincijskoj upravi.

${ }^{61}$ BOA, C.ML 30261.

${ }^{62}$ BOA, C. ML 14885.

${ }_{63}$ "bu makûle vâridât-ı mukâtaca-yı mîrîyyenün kesr ve hasâreti muceb olur halâtdan himâyet ve siyânet lâzime-i hâldan olmagla”. BOA, C.ML 23446.

64 "Mezbûr makûleleri hilâf-ı şurût ve mugâyır-ı kadîm hâsıl olan mahsûlâtun $a^{c} s ̧ \hat{a} r-1$ şerciyye ve rüsûmat-ı sẫiresine tacarruz ve müdâhale ve ol takrîbiyle mukâtaca-yı mezbûrenün ihtilâlına ve mâl-i mîrînün kesrine bâdî olmalar ile”. BOA, C.ML 14885. 


\section{Alternativna rješenja na mukatama u Bosanskom ejaletu: Zadržavanje tradicionalnih izvora državnih prihoda}

Prethodna poglavlja pokazala su da su krajem 17. i početkom 18. stoljeća na velikom broju zemljišnih jedinica u Bosanskom ejaletu ukinute paušalne daće i vlaški porezi, a zavedena desetina i prateća podavanja, kao i da pojedini izvori govore čak i da je većina državnih mukata bila prevedena na režim desetine, što se za sada ne može provjeriti. Prema tome, jasno je da su postojale i mukate na kojima se opredijelilo za "alternativno" rješenje, odnosno za zadržavanje ranijeg sistema ubiranja podavanja, što je u ovom poglavlju označeno izrazom tradicionalni izvori državnih prihoda, pod čim se misli na ono što je bilo zabilježeno u "starim", ali još važećim katastarskim defterima, koji su nastali najkasnije početkom 17. stoljeća. Odgovor na pitanje zašto mjera o prijelazu na režim desetine nije primijenjena na sve mukate, kao i šta je to značilo za stanovništvo, predmet je ovog poglavlja.

Na prvom mjestu, potrebno je pokazati da je uopće bilo mukata na kojima su u 18. i prvim decenijama 19. stoljeća bili ubirani filurija i podavanja odsjekom. Cilj ovog poglavlja nije donošenje sveobuhvatnih podataka o svim mukatama na kojima je bio zadržan sistem ubiranja podavanja, koji je zatečen početkom 17. stoljeća, nego prije svega detektiranje pojedinih primjera ovakvih mukata koji mogu poslužiti za donošenje zaključaka o ovoj osmanskoj finansijskoj praksi i njenim posljedicama. Na osnovu njih došlo se do važnog zaključka, da bez obzira što je u ranije navedenim poglavljima, istaknuto da je većina mukata u Halil-pašino doba bila prevedena na režim desetine, to ne znači da su površine koje su ostale pod filurijom i podavanjima odsjekom bile beznačajne. Naprotiv, na osnovu podataka kojima trenutno raspolažemo, može se zaključiti da se radilo o prilično velikim zemljišnim površinama, koje su se nalazile na različitim stranama Bosanskog ejaleta.

Naprimjer, dovoljno je reći da je područje Kobaške mukate, koje je i nakon Halil-pašinog vremena zadržalo filuriju kao osnovnu daću, obuhvaćalo brojna sela u sjevernoj Bosni, na području nahija Kobaš, Banjaluka, Lefče/ Lijevče, Vrbaški, Dobor, Zmijanje, Trebava/Trijebovo, Kotor, Vrhovine i 
Fahd Kasumović, Rekonceptualizacija transformacijskih procesa na periferiji Osmanskog Carstva: filurija i prijelaz na režim naturalne desetine u agrarnoj ekonomiji osmanske Bosne, c. 1699-1852.

Jajce. ${ }^{65} \mathrm{Na}$ osnovi podatka osmanskih zvaničnih registara, koji su nastali polovinom 18. stoljeća, vidi se da su zakupci poreza koji su držali ovu mukatu zahtijevali u 18. stoljeću od posjednika zemlje filuriju, kao i da je vlast to smatrala zakonitim. ${ }^{66}$

Obaveza plaćanja filurije zadržana je i na područjima oko Tešnja i Maglaja, koja su ulazila u sastav osmanske mukate poznate, između ostalog, pod nazivom Mukata vlaških poreza Tešnja i Maglaja s pripadajućih prihodima. ${ }^{67}$ Osim toga što se ova daća spominje kao legitimni prihod u bujuruldijama bosanskih namjesnika iz tridesetih godina 19 . stoljeća, ${ }^{68}$ sačuvane su i tapije zakupnika ovog poreza, lokalnih kapetana, u kojima je izričito spomenuta obaveza plaćanja filurije. ${ }^{69}$

Filuriju je moguće susresti kao legitimnu daću i na području Hercegovine. Naprimjer, ona je još u 19. stoljeću bila smatrana važećom poreskom obavezom u selu Ravno, u nahiji Popovo, ${ }^{70}$ kao i u nekim selima u blizini

${ }^{65}$ Ovo se vidi iz jednog popisa baština na Kobaškoj mukati koji je, kako se vidi iz različitih bilješki, pripadao osobi koja je polovinom 18. stoljeća držala u zakupu ovu finansijsku jedinicu. GHB, A-4855/TO-30.

${ }^{66}$ Zakupnik Kobaške mukate žalio se polovinom 18. stoljeća na to da mu stanovnici odbijaju prema zakonu i defteru platiti filuriju. Carskom naredbom iz 1749. (1162. AH) bilo je naređeno da se plaćanje vrši prema zakonu, čime je vlast pokazala da je filurija na navedenom području bila legitimna daća, te je podržala zakupnikovo pravo da je ubire. BOA, A.DVNS.AHK.BN.d 1, 191. Nekoliko decenija nakon ovoga, povjerenik (emin) na Kobaškoj mukati izdao je potvrdu o naplaćenoj filuriji iz koje se vidi da je Hadži Mustafa, dizdar tvrđave Jajce, posjednik nekih filurijskih baština, platio filuriju za 1780. (1194. AH). GHB, A-4855/629.

${ }^{67}$ Početkom 18. stoljeća ona se navodi pod nazivom Mukâtaca-yı rüsûm-ı Eflâkân-ı Maglayve Teşne. BOA, D.BŞM.BNH.d 16771, 4. Kasniji popisi osmanskih mukata pokazuju i različite varijacije u ovom naslovu u zavisnosti od toga s kojim prihodima su spomenute daće bile spojene. Naprimjer, u jednom popisu mukata se za 1813. (1228. AH) navode državni prihodi na finansijskoj jedinici koja je označena kao Mukata vlaških poreza, divanskih avariza, tapijskih pristojbi i badihave Tešnja. BOA, MAD.d 3420, 10v.

${ }^{68}$ Vidjeti dokumente iz maglajskih sidžila: Dušanka Bojanić i Tatjana Katić (prev.), Maglajski sidžili 1816-1840, Sarajevo: Bošnjački institut - Fondacija Adila Zulfikarpašića, 2005, 162-164, 555-557.

${ }^{69}$ Hadži Ibrahim, kapetan, izdao je 1810/11. (1225. AH) tapiju za zemlju u Maglajskoj nahiji u kojoj se spominje obaveza plaćanja filurije. ABiH, ZPO, dok. br. 26.

${ }^{70}$ Nekoliko muslimanskih posjednika baština tvrdili su 1802. u jednoj molbi upućenoj centralnoj vlasti da su uredno plaćali filuriju za baštine koje su držali u svom posjedu. Naveli su da je ova filurija pripadala Mukati hercegovačkih Vlaha (Mukâtacîa-yı Eflâkân-ı Hersek). Međutim, 
Gabele, na Mukati vlaških poreza Nevesinja s pripadajućim prihodima. ${ }^{71}$

Zanimljivo je da je osmanska vlast na nekim područjima više puta mijenjala režim ubiranja prihoda, te da je ponekad čak dolazilo i do zvaničnog vraćanja filurije, nakon što je jednom bila ukinuta. Za sada, čini se da je vraćanje filurije bilo ograničeno na manje oblasti, ali se ona ni u njima nije mogla duže održati zbog "pritiska” zakupnika i značaja koji je izdavanje poreza u zakup imalo za finansijsku strukturu Osmanske države. Primarni izvori sadrže podatke iz kojih se vidi da je do privremenog vraćanja filurije u 18. stoljeću, došlo u nahiji Završje, u Fočanskom kadiluku, koja je pripadala Mukati hercegovačkih vojnuka. Ova je finansijska jedinica početkom 18. stoljeća bila prevedena na desetinu, da bi 1775/76. (1189. AH) došlo od zvaničnog vraćanja filurije, ali ne na cijeloj mukati, već samo u nekim njenim dijelovima, kao što je nahija Završje. ${ }^{72}$ Zvanični karakter vraćanja filurije se vidi iz toga što je o tome bila izdata carska naredba. Međutim, navedena naredba nije dugo ostala na snazi te se, nakon žalbi zakupnika, 1778. susreće nova naredba kojom su poništeni raniji upisi i vraćena desetina. ${ }^{73}$

Od posebnog značaja za dokazivanje teze o transformacijskim procesima u Bosanskom ejaletu, što je ključna teza ovog rada, predstavlja detektiranje

službenici finansijskih kancelarija na margini su naveli finansijsku jedinicu, kojoj je pripadalo Ravno pod nazivom Mukata vlaških poreza Nevesinja i ...[nepročitano] s pripadajućim prihodima (Mukâtaca-yı rüsûm-ı Eflâkân-ı Nevesin ve...ve tevâbicuhâ). BOA, C.ML 6860. Ova je jedinica označena u jednom od popisa mukata iz druge decenije 19. stoljeća samo kao "Mukata vlaških poreza Nevesinja s pripadajućim prihodima”. BOA, MAD.d 3420, 79v.

${ }^{71} \mathrm{Za}$ neka sela u nahiji Gabele se navodi 1820. da su izbjegavala plaćanje filurije, ali se, također, vidi i da je ona smatrana važećom daćom na ovom području. BOA, C.ML 10182.

${ }^{72} \mathrm{Ne}$ može se sa, za sada, sigurnošću znati koji je broj sela ove nahije bio podvrgnut ovim promjenama, kao i da li je bilo sličnih slučajeva izvan spomenute nahije.

${ }^{73} \mathrm{Za}$ nahiju Završje sačuvano je više međusobno povezanih dokumenata, uključujući i molbe zakupnika, kaime bosanskih namjesnika, izvještaje glavnog defterdara, izvode iz katastarskih popisnih deftera i popisa osmanskih zakupnih jedinica, kratke bujuruldije velikih vezira, kao i više fermana, uključujući onaj o ponovnom uvođenju desetine iz 1778. Ovi dokumenti povezani su s ranije citiranim dokumentima o Mukati Hercegovačkih vojnuka, ali oni daju i nove podatke koji upotpunjuju razumijevanje osmanskog postupanja s navedenom mukatom i problemima vezanim za filuriju i desetinu. Neki dokumenti čak spominju ovo područje i kao Mukatu Završje. BOA, C.ML 10074; BOA, 23446. 
mukata koje su nakon Halil-pašinog vremena zadržale režim filurije, da bi tek mnogo iza toga bile prevedene na desetinu. Navedene su mukate značajne budući da ukazuju na postepenost osmanske politike prevođenja mukata na režim desetine, odnosno da je taj proces zasnovan na odlukama, koje je centralna vlast donijela u različitim periodima. Imajući to u vidu, važno je napomenuti da su sela na Mukati vlaških poreza Tašlidže (Pljevlja) i Prijepolja tek 1794. (1208. AH) godine prebačena na sistem desetine, nakon što je procijenjeno da baštine o kojima je riječ mogu podnijeti tu obavezu (ifâ-yı öşr mütehammil oldı̆̆ına mebnî). ${ }^{74}$

Postavlja se pitanje zbog čega je država odlučila zadržati stari režim ubiranja državnih prihoda na ovih mjestima, dok je to drugdje promijenila. Osnovni razlog za ovo treba tražiti u tome što je za ove mukate mogla pronaći zakupce bez "većih" problema, te da, zbog toga, nije bilo nužno izvršiti prevođenje na desetinu. Zapravo, na ovim područjima vlast se poslužila drugom strategijom kako bi privukla potencijalne zakupce. Naprimjer, u nekim slučajevima ogromna su područja bila uvrštena u mukatu, kao što pokazuje primjer Kobaške mukate, dok su negdje vlaški porezi bili spojeni $\mathrm{s}$ drugim prihodima u jednu mukatu, ${ }^{75}$ kao naprimjer u slučaju Maglaja i Tešnja, tako da se time moglo pronaći zakupce. ${ }^{76}$ Zapravo, osmanski popisi mukata uglavnom pokazuju da su ove mukate bile operativne, uz određene situacije, kada se prihod nije mogao sakupiti. Također, na nekima od njih su, kao što je Kobaš, bile ustanovljene i prilično velike godišnje zakupnine. ${ }^{77}$

Struktura tih mukata, prema tome, bila je tokom većeg dijela 18. i prvih decenija 19. stoljeća, izuzimajući pojedine krizne situacije, dovoljno

\footnotetext{
${ }^{74}$ Doživotni zakupac ove mukate bio je Ibrahim-paša, za kojeg se navodi da je bio nastanjen (mukîm) u Travniku. On je uputio molbu da se ova mukata prevede na režim desetine. BOA, C.ML 29676.

${ }^{75}$ Vidjeti ranije citirani popis baština Kobaške mukate iz polovine 18. stoljeća.

${ }^{76}$ Naprimjer, vlaški porezi Tešnja bili su 1730/31. (1143. AH) spojeni s badihavom, tapijskim pristojbama i divanskim avarizima na navedenom području, kao i s carinskim prihodima koji su ubirani na skeli u Zvorniku. BOA, MAD.d 10182.

${ }^{77}$ Mukata vlašakih poreza Kobaša iznosila je 1700/1701. (1112. AH) 1.500 .000 akči. Bila je, u to vrijeme, druga mukata po visini godišnjih prihoda u Bosanskom ejaletu, kao i najkrupnija mukata vlaških poreza među mukatama vlaških poreza. BOA, 16771, 4.
} 
atraktivna da privuče osmansku vojno-administrativnu elitu da uloži svoj novac u poslove doživotnog zakupa. Međutim, zanimljivo je, ipak, da su zakupci državnih prihoda, na koje su polagali legitimno pravo na osnovu carske naredbe koja im je bila izdata nakon održane licitacije i sklopljenog zakupničkog odnosa, pribjegavali i sredstvima koja nisu bila zakonita kako bi povećali svoj prihod. Na osnovu žalbi koje je centralna vlast primala, može se zaključiti da su zakupci pokušavali ubirati više novčane iznose od onih koji su bili predviđeni u važećim katastarskim popisnim defterima. Zahtijevani su viši iznosi kako na mjestima na kojima je bio ubilježen paušalni iznos $\left(m a k t \hat{u}^{c}\right){ }^{78}$ tako i viši iznosi filurije, što je, na koncu, dovodilo do sporova na lokalnom nivou, o kojima je vijest dolazila i do prijestolnice. ${ }^{79}$

Reakcija centralne vlasti na ovom polju bila je u skladu s osmanskom politikom slijeđenja važećih zakonskih propisa i iznosa koji su bili legitimni. Zbog toga, u nekim naredbama izdatim u vezi sa pritužbama se kratko poručivalo - "U skladu s carskim defterom, neka se postupi prema zakonu”. ${ }^{80}$ Ovo je značilo da je vlast podržala oštećene posjednike, jer zakoniti iznosi su bili oni koji su stajali u važećim defterima, ukoliko nije bilo njihove naknadne korekcije, a u navedenim primjerima ona se nije desila. Međutim, osim carske naredbe, koja je mogla biti i deklarativne prirode, nema podataka o nekim konkretnim sankcijama, odnosno kako je to bilo provedeno na terenu.

Također, osim ovoga, zabilježeno je i da su pojedini zakupci filurijskih mukata manipulirali kursnim razlikama kako bi stekli dodatni prihod. Naime, u klasičnim defterima iznosi koji su im posjednici baština unutar mukate trebali platiti bili su ubilježeni u akčama, dok ova novčana jedinica u 18. stoljeću nije više korištena kao operativno sredstvo plaćanja zbog

\footnotetext{
${ }^{78}$ Mustafa Mehdić se 1746. žalio centralnoj vlasti na zabite na Kobaškoj mukati, tvrdeći da su uzimali nekoliko puta više iznose paušalne daće u odnosu na ono što je stajalo u poimeničnom katastarskom defteru. BOA, A.DVNS.AHK.BN. 1, 145.

${ }^{79}$ Ulema i tvrđavski posadnici su se 1767. žalili na zakupnike Kobaške mukate, te su u kolektivnoj predstavci vlastima tvrdili da su zakupnici tražili od "raje i beraje" povišeni iznos filurije. GHB, A-4855/TO-102.

80 “Defter-i hakânî mücebince kânûn üzere amel olınmak”. BOA, A.DVNS.AHK.BN. 1, 145, 191.
} 
ogromne devalvacije, ali se, s druge strane, redovno susreće kao obračunska jedinica. Zbog toga, zakupci su, prilikom preračunavanja novčane obaveze u defterima u ono što je realno trebalo platiti u skladu s monetarnim prilikama 18. stoljeća (u grošima i parama), koristili kurseve koji su njima išli u korist, a ne posjednicima baština, što je, također, dovodilo do žalbi. Centralna vlast i u ovom slučaju je kratko poručivala da je potrebno postupiti prema zakonu, što nije dovoljno da se iz dokumenata vidi kako je konkretno bio razriješen na terenu navedeni slučaj. ${ }^{81}$

Međutim, nisu samo zakupnici bili ti koji su činili određene zloupotrebe. Oni su nekada mogli biti i oštećena strana budući da su stanovnici znali izbjegavati plaćanje legitimnih poreza na koje su zakupci imali pravo. Ovo je centralna vlast ocjenjivala kao gubitak državnog novca, te je u takvim slučajevima izdavala naredbe kojima je trebalo zaštiti legitimna prava osmanskih zakupnika. ${ }^{82}$

Kada se sve navedeno uzme u obzir, dolazi se do zaključka da se važna faza u prevođenju državnih mukata u Bosanskom ejaletu na režim naturalne desetine i pratećih podavanja odigrala na prijelazu iz 17. u 18. stoljeće, ali da su i dalje značajna područja u navedenoj provinciji ostala uključena u mukate koje su funkcionirale u skladu s tradicionalnim propisima, odnosno na njima su i dalje nastavljeni biti ubirani filurija i podavanja određena odsjekom. Centralna vlast pronašla je alternativne načine da ove mukate učini atraktivnim potencijalnim zakupcima, uglavnom tako što ih je spojila s nekim drugih prihodima, te uključivanjem velikih površina u sastav mukate. Neke od ovih mukata bile su prevedene na režim desetine krajem 18. stoljeća, što je dodatni dokaz u korist teze ovog rada da je prijelaz

\footnotetext{
${ }^{81}$ Izvjesni Husejin žalio se 1760. na povjerenike Kobaške mukate zbog toga što su zahtijevali filuriju u "zdravim/jakim akčama" (sağ akçe), umjesto u "slabim akčama” (çürük akçe). U fermanu koji je povodom ovoga bio izdat je navedeno da se uživaoci malikane nisu zadovoljili obračunavanjem po kursu (rayiç) za slabu akču, što je bilo uobičajeno u Bosni, te da su vršenjem obračuna prema računu za "zdravu akču", navodno, "udvostručavali" iznose koje su naplaćivali (iki kat resm-i filûrî mutâlebesiyle). BOA, D.BŞM.BNH 7/5.

${ }^{82}$ Malikanedžija Kobaške mukate žalio se 1749. da nije mogao naplatiti filuriju "prema zakonu i defteru". BOA, A.DVNS.AHK.BN.d 1, 191.
} 
na režim desetine u Bosanskom ejaletu potrebno promatrati kao proces $\mathrm{s}$ različitim fazama. Također, ovi slučajevi pokazatelj su varijacija u politici centralne vlasti prema različitim područjima u državi, te dokaz o njenoj sposobnosti da se prilagodi lokalnim okolnostima, kao i potražnji državnih zakupa među pripadnicima socijalne elite, dok je osnovni cilj, pri tom, ostajao isti - održavanje efikasne finansijske strukture Osmanske države.

\section{Predtanzimatski val finansijskih promjena: Akcija prevođenja državnih mukata na naturalnu desetinu tridesetih godina 19. stoljeća}

Doba od kraja 18. stoljeća do proglašenja tanzimatskih reformi (1839.) određeni istaknuti osmanisti smatraju vremenom u kojem je centralna vlast vodila novu finansijsku politiku, te u kojem je došlo do značajnih institucionalnih reformi u Osmanskom Carstvu. No, o osmanskoj politici prema Bosanskom ejaletu, a pogotovo o finansijskim promjenama koje su se desile u godinama koje su prethodile proglašenju tanzimatskih reformi malo se zna. Historiografska literatura koja se bavila ovim razdobljem uglavnom se posvetila vojnim reformama, te se o promjenama na polju finansija može susresti samo nekoliko rečenica. ${ }^{83}$ Međutim, ovo je bilo doba kada su se desile važne promjene u pogledu režima ubiranja državnih prihoda na mukatama, o čemu se ovdje govori kao o dijelu šireg vala promjena koje su zahvatile Osmansko Carstvo u decenijama koje su neposredno prethodile tanzimatskim reformama. Riječ je o novoj akciji prevođenja filurijskih mukata na režim desetine, te će se u glavnom dijelu ovog poglavlja predstaviti ova akcija i njene finansijske i društvene posljedice.

Dokaz tome da je osmanska vlast tridesetih godina aktivno radila na tome da promijeni režim ubiranja državnih prihoda na onim mukatama na

\footnotetext{
${ }^{83}$ Aličić uopće ne navodi bilo kakve finansijske promjene u Bosanskom ejaletu tridesetih godina 19. stoljeća. Za sada, jedine informacije koje o tome postoje su nekoliko rečenica koje su o tome dale D. Bojanić i T. Katić u svom izdanju maglajskih sidžila, koje sadrži i dva važna dokumenta o prevođenju bosanskih mukata na režim desetine (Bojanić i Katić, Maglajski sidžili, 159, 162-164). No, u cjelini gledano, ovom pitanju nije posvećena posebna pažnja, niti je ono povezano sa širim osmanskim transformacijskim procesima.
} 
kojima su još uvijek bili ubirani filurija i podavanja odsjekom, pronalazimo u dvije bujuruldije bosanskog namjesnika Mehmed Salih Vedžihi-paše (1835-1840) iz 1837. i 1838. One su vanredno važne za razumijevanje ove pojave, kao i za utvrđivanje načina na koji je ona bila provedena. Na osnovu njih može se zaključiti da je akcija vlasti na prevođenju preostalih filurijskih mukata u Bosanskom ejaletu na režim desetine doživjela novi val u vrijeme Davud-paše, koji se na namjesničkoj poziciji nalazio u periodu od 1833. do 1835.

Na osnovu Mehmed Vedžihi-pašine bujuruldije iz 1837. se vidi da je u Davud-pašino vrijeme bio održan sastanak carskog izaslanika s Davudpašom i visokim funkcionerima ejaleta, te da je tom prilikom bila donijeta odluka da se sve mukate u Bosanskom ejaletu na kojima je ubirana filurija prevedu na desetinu. Njihov prihod trebalo je ostaviti starim uživaocima, a višak prihoda koji se pojavi trebalo je preusmjeriti za potrebe pokrivanja troškova "Pobjedničke redife" (redîfe-i mansûre), odnosno vojne rezerve koju je trebalo oformiti i za koju je trebalo popisati vojnike. ${ }^{84}$

Dispozicija navedene bujuruldije sadržavala je naredbu koja je adresate obavještavala o mjerama koje su donijete i koje treba provesti. Bilo je naređeno da se od poljoprivrednih proizvoda na mukatama ubuduće uzima "ušur" (desetina), te je izričito precizirano da to iznosi jedan deseti dio uroda. Bio je osmišljen i alternativni način ispunjavanja ove obaveze. Naime, za one koji ne bi u svom posjedu imali ljetinu, bilo je moguće da ispune svoju obavezu plaćanja desetine u novčanom vidu u skladu s tekućim cijenama u provinciji (memleketin râyici üzere). ${ }^{85}$

${ }^{84}$ Prema A. C. Erenu, u Bosni se 4. novembra 1835. počelo s popisivanjem konjaničke rezerve (Ahmet Cevat Eren, Mahmud II. Zamaninda Bosna-Hersek, Istanbul: Nurgök Matbaası, 1965, 153). U bujuruldiji Mehmed Vedžihi-paše, od 31. oktobra 1835. godine, se navodi da se, u skladu s naredbom i carskom iradom, trebalo posvetiti pažnju "popisivanju rezerve Pobjedničke vojske" (redîf-i asâkir-i mansûresinin tahrîri). Na nekim je mjestima nešto vojnika popisano, ali, kako se navodi, na većini mjesta to još uvijek nije bilo učinjeno. Naređeno je da se što prije opreme i zabitu/oficiru predaju vojnici koji su "prije ovoga" (bundan mukaddem) bili raspoređeni na Sarajevski kadiluk. GHB, Sidžil 75, 27-28.

${ }^{85}$ D. Bojanić i T. Katić, Maglajski sidžili, 162-163, 555-556. 
Navedena mogućnost novčanog plaćanja bila je u Mehmed Vedžihipašinoj bujuruldiji iz 1838. izražena na nešto drugačiji način te se u njoj navodilo da je bilo moguće ispuniti obavezu tako što će se na filuriju dodati određeni iznos. Naglašeno je da je sve ovo bilo u skladu sa zahtjevima "visoke irade", odnosno carskog dokumenta o ovom pitanju, koji još uvijek nije pronađen. ${ }^{86}$

Zašto je uopće bila donijeta ovakva odredba, šta je ona značila i da li su ove mjere centralne vlasti označile kraj za ubiranje filurije u Bosanskom ejaletu?

Razlozi za donošenje ovih mjera bili su finansijske prirode, te ih treba promatrati kao rezultat višedecenijskog iskustva koji je osmanska vlast imala s rješavanjem problema na filurijskim mukatama i gubicima koji su se dešavali na ovom polju zbog inflacije. Ranije je u ovom radu pokazano da je državni prihod bio manji na baštinama pod filurijom, nego na onim koje su bile pod desetinom, kao i da je vlast toga bila svjesna. Također, vlast je bila dobro informirana i o pokušajima zakupaca filurijskih mukata da manji prihod nadoknade samovoljnim nametima, kako bi vratili investiciju u poduhvat zakupljivanja poreza, odnosno kako bi zaradili. ${ }^{87}$ Odlučnost države da riješi te probleme aktualizirana je u predtanzimatskom vremenu, a tome je, po svemu sudeći, doprinijela i primijetna reformistička klima u državi - sultan i centralna vlast bili su tada spremniji na pravljenje rezova u odnosu na ranije stanje i tradicionalne upravne prakse.

Osim toga, evidentno je da je vlast višak koji se ostvari prevođenjem na režim desetine, odnosno doplaćivanjem do iznosa koji je smatran ekvivalentom naturalnoj desetini, namjeravala preusmjeriti za finansiranje vojnih odreda koje je oformila u skladu s reformnim nastojanjima, odnosno za konjičku rezervu (süvârî redîfe), kako se ovaj korpus nazivao u primarnim izvorima. Međutim, za sada je teško procijeniti finansijski značaj ove odredbe, budući da se ne zna koliko se na ovaj način moglo sakupiti novca. U svakom slučaju, jasno je da ovo nije bio jedini način fi${ }^{86}$ Isto, 164, 590-591.

${ }^{87}$ Ovo je izvedeno iz dokumenata koji su obrađeni u prethodnim poglavljima. 
Fahd Kasumović, Rekonceptualizacija transformacijskih procesa na periferiji Osmanskog Carstva: filurija i prijelaz na režim naturalne desetine u agrarnoj ekonomiji osmanske Bosne, c. 1699-1852.

nansiranja redife, nego samo jedan od izvora prihoda koji je bio usmjeren u ove svrhe. ${ }^{88}$

Navedena mjera koja je poduzeta u Davud-pašino i Mehmed Vedžihipašino vrijeme nije predstavljala konačni kraj filurije kao podavanja na mukatama u Bosanskom ejaletu, mada se na prvi pogled može tako činiti. Međutim, pravilnije je reći da je ona predstavljala kraj filurije kakva je do tada postojala - kao fiksni iznos koji se zasnivao na osmanskim katastarskim popisnim defterima. Umjesto toga, ubuduće je mogla biti ubirana filurija kao ekvivalent za vrijednost naturalne desetine, u skladu sa tržišnim cijenama desetine u Bosanskom ejaletu.

Nakon ovoga, moguće je susresti u primanim izvorima filuriju kod koje su bili jasno razgraničeni stari iznos filurije, odnosno ono što je bilo upisano u katastarskim popisima i novi iznos filurije koji je činio dodatak na ovaj iznos. Naprimjer, na osnovu potvrda o plaćenoj filuriji koji se odnose na zemljišta koja su pripadala Kobaškoj mukati, vidi se da su čifluk sahibije iz banjalučke porodice Đumišić, plaćali državi (cânib-i mîrîye) daću koja je označena kao "stara i dodatna filurija" (kadîm ve zamm filûrisi), pod čim se podrazumijevao iznos koji je trebalo platiti da bi se dostigao procijenjeni ekvivalent za desetinu na zemljištu koje su spomenute osobe držale u svom posjedu. ${ }^{89}$

Navedeni podaci pokazuju da tridesete godine 19. stoljeća u Bosni nisu protekle samo u provođenju određenih vojnih reformi, nego su se desile i određene promjene na finansijskom polju. Odlučeno je da se preostale državne mukate u Bosanskom ejaletu prevedu na naturalnu desetinu, odnosno da se posjednicima zemljišnih jedinica omogući da, ukoliko to žele, plaćaju

\footnotetext{
${ }^{88}$ Postoje podaci i o drugim državnim prihodima koji su bili usmjereni za izdržavanje konjaničke rezerve. Državni prihod koji je ostvarivan prilikom inspekcije rakijskih kazana (kazgan teftişiyyesi) bio je ustupan u zakup te se, na osnovu dokumenta iz sarajevskih sidžila, može zaključiti da je i on služio za finansiranje konjaničke rezerve. GHB, Sidžil 76, 223.

${ }^{89}$ Navedeno se vidi iz potvrde koju je 1844. nadležni državni službenik izdao Abid-agi Đumišiću (Sîm-zâde). Nije bilo navedeno selo na koje se ovo odnosilo. Međutim, na osnovu više dokumenata koji se čuvaju u Gazi Husrev-begovoj biblioteci u Sarajevu, vidi se da su Đumišići tradicionalno držali neka od zemljišta koja su pripadala Kobaškoj mukati. GHB, A-4855/TO-616.
} 
novčani iznos koji će, u skladu s tržišnim cijenama u provinciji, biti ekvivalentan naturalnoj desetini. Ova odluka važna je za razumijevanje predtanzimatske faze u osmanskim transformacijskim procesima na području Bosanskog ejaleta. Međutim, ne može se reći da je ova mjera značila i konačni kraj filurije kao podavanja na mukatama. Adekvatniji zaključak je da se radilo o kraju filurije kao daće koja je bila vezana za iznose iz katastarskih popisnih deftera. Koliko je to bio značajan korak za osmanske finansije vidi se, između ostalog, iz činjenice da je ovim činom osmanska vlast konačno napustila neke mjere koje su bile stare više od dva stoljeća, te je time dodatno potvrdila spremnost na promjenu i napuštanje za državu štetnog oslanjanja na administrativne tradicije i regulativu iz klasičnog razdoblja.

\section{Vlaški porezi, paušalne novčane daće i timarski sistem, c. 1699-1852}

Dosadašnji tok predstavljanja transformacijskih procesa na polju provincijskih finansija u Bosanskom ejaletu uglavnom je bio fokusiran na pitanje ukidanja vlaških poreza i paušalnih novčanih daća na mukatama, te njihovo mijenjanje režimom desetine i pratećim novčanim daćama. Obrada ovih finansijskih jedinica i jeste najznačajnija za razumijevanje fenomena o kojem se govori u ovom radu, budući da su glavni predmeti tih mukata bili carskih hasovi, kojima je u 18. stoljeću bio pripojen i dio namjesničkih hasova, a upravo je u defterima iz klasičnog razdoblja većina vlaških poreza u zapadnobalkanskim sandžacima registrirana kao prihod ovih vrsta posjeda. Međutim, filurije i podavanja odsjekom bilo je i na timarima i zeametima u zapadnobalkanskim sandžacima u klasičnom razdoblju, ${ }^{90}$ što otvara nekoliko važnih pitanja: Šta se desilo s navedenim podavanjima u 18. i 19. stoljeću? Da li je i unutar timarskog sistema moguće govoriti o transformacijskim procesima, na prvom mjestu, da li je i na tom polju bilo slučajeva prevođenja filurijskih zemljišta na naturalnu desetinu?

Osnovna tvrdnja koja se zastupa u ovom poglavlju je da je timarski sistem jednim dijelom bio zahvaćen transformacijskim procesima, te da je

\footnotetext{
${ }^{90}$ S. Buzov, "Vlasi u bosanskom sandžaku”, 107.
} 
dio timara i zeameta u Bosanskom ejaletu još u 18. stoljeću bio preveden na režim desetine, dok je, paralelno s tim, na dijelu timara i zeameta bio zadržan raniji režim ubiranja državnih prihoda u vidu filurije i podavanja odsjekom. Navedeni različiti režimi u ubiranju državnih prihoda, koje treba shvatiti kao paralelna rješenja, zadržali su se do kraja postojanja timarskog sistema u Bosanskom ejaletu, polovinom 19. stoljeća.

Dokaze koji upućuju na zaključak da je prevođenje na režim desetine zahvatilo u 18. stoljeću i sektor na kojem su državne prihode sakupljali zaimi i spahije predstavljaju izvodi iz katastarskih popisnih deftera, koji su u određenim slučajevima sadržavali i dodatne zabilješke da se na nekom timaru ili zeametu desila promjena u pogledu vrste prihoda koji su ubirani. Naprimjer, državna administracija sastavila je 1835. izvod iz opširnog popisa Kliškog sandžaka koji se odnosio na zemljišta čiji je prihod pripadao zeametu Sulejmana, sina Osman-begovog. Na njegovoj margini bila je unijeta zabilješka da je 1718. izvršena korekcija u pogledu prihoda ovog zeameta prema kojoj su baštine koje su do tada plaćale filuriju bile prevedene na desetinu. Razlog za ovu promjenu bio je to što se utvrdilo da filurija nije bila ekvivalentna desetini (öşre mucâdil olmayup), te su prihodi zeameta bili mali (kalîl olup). Kako se navodi, oni nisu dostajali za pokrivanje ratnih troškova koje je uživalac zeameta imao. ${ }^{91}$

Navedeni dokument značajan je jer nedvojbeno dokazuje mogućnost legitimnog i legalnog ukidanja filurije i prijelaza na režim desetine unutar timarskog sistema u Bosanskom ejaletu, što do sada nije bilo poznato $\mathrm{u}$ historiografiji. Historičari koji su se bavili ovom problematikom do sada su samo predstavljali samovoljne napore zaima i spahija da promijene režim ubiranja prihoda. ${ }^{92}$ Raspravljalo se o zavođenju desetine isključivo kao o vidu zloupotrebe, te se propustilo vidjeti da nisu svi slučajevi nelegalni, nego da je centralna vlast i sama ponekad odlučivala promijeniti režim ubiranja prihoda, kako bi povećala prihod koji je bio dodijeljen vojnicima.

\footnotetext{
${ }^{91}$ Navedena promjena bila je unijeta i u sumarni defter Kliškog sandžaka. GHB, A-4772/T0.

${ }_{92}$ A. Sućeska, "Pokušaj muslimanske raje”, 195.
} 
Zasada, nema dokaza da je u 18. stoljeću bilo neke masovne akcije prevođenja na desetinu filurijskih baština čiji je prihod bio vezan za timare i zeamete, kao što je to slučaj s državnim mukatama. Navedeni primjer daje opravdanu osnovu za pretpostavku da je moglo biti još sličnih slučajeva, dok bi pronalazak novih dokumenata mogao omogućiti donošenje nekog čvršćeg zaključka o obimu ove pojave na području Bosanskog ejaleta.

Osim ovoga, važno je napomenuti da postoji više dokaza koji pokazuju da je centralna vlast na određenim timarima i zeametima u Bosanskom ejaletu tokom 18. stoljeća i dalje smatrala filuriju legitimnom daćom. Naprimjer, polovicom 18. stoljeća bilo je izdato više carskih naredbi kojima su osuđene nezakonite aktivnosti zaima i spahija u Bosni na filurijskim zemljištima, u prvom redu samovoljno ubiranje desetine, ${ }^{93}$ kao i ubiranje određenih dodatnih podavanja, povrh filurije. ${ }^{94}$ Također, zabranjivane su i slične zloupotrebe na zemljištima na kojima su ubirana paušalna podavanja. ${ }^{95}$ Bilo je naređeno da se to spriječi, te da se porez ubire "u skladu sa zakonom i defterom", a tu se radilo o katastarskim popisnim knjigama koje su nastale najkasnije početkom 17. stoljeća. Pored carskih naredbi, moguće je susresti i namjesničke bujuruldije kojima su ovakve zloupotrebe rješavane. ${ }^{96}$

Ovakvi slučajevi pokazatelj su opredjeljenja osmanskih vlasti da se u timarskom sistemu zadrže stara zakonska regulativa i defteri te da se spriječi samovolja lokalnih spahija i zaima. Zanimljivo je da u nekim slučajevima

${ }^{93}$ Prema jednoj carskoj naredbi iz 1748. godine, zaim Ibrahim ubirao je desetinu na mjestima na kojima je bila ubilježena filurija. Nakon što su se posjednici žalili, izdata je carska naredba da se postupi u skladu s onim što je bilo od davnina zabilježeno, odnosno da se ne ubire desetina. BOA, A. DVNS.AHK.BN.d 1, 172-173.

${ }^{94}$ Omer Đumišić, koji je kao čifluk sahibija držao određene filurijske baštine u selu Krupa, žalio se 1752. da je nadležni spahija od raje na tim baštinama, koje su bile njegov čifluk, tražio da plate više od predviđenog (zevayidât iddicâsıla). GHB, A-4855/TO-32.

${ }^{95}$ Osman-beg Dženetić je tražio polovinom 18. stoljeća od stanovnika sela Tuholj, u blizini Kladnja, da mu plate desetinu, umjesto podavanja koja su bila paušalno određena kao novčani ekvivalent za desetinu na sijeno. Carskom naredbom je naređeno da se postupi po zakonu i defteru. BOA, A.DVNS.AHK.BN.d 1, 210.

${ }^{96}$ GHB, A-4855/TO-32. 
centralna vlast izlazi u susrest ovom vojničkom sloju i omogućava im izmjenu režima ubiranja prihoda, kao što je ranije pokazano, dok na drugim mjestima to odbija učiniti. Međutim, nije uspjela riješiti ni njihove probleme i manjak prihoda koji im je oslonac na stare deftere stvarao, te su se ovakvi slučajevi i dalje nastavili dešavati.

Filurija je smatrana legitimnom daćom na nekim timarima i zeametima u Bosanskom ejaletu i u 19. stoljeću te se, između ostalog, krajem treće decenije mogu susresti tapije koje su izdavale lokalne spahije u kojima se jasno navodi da su im posjednici baština dužni plaćati filuriju na godišnjoj osnovi. ${ }^{97}$ Nema indicija da se to promijenilo ni nakon proglašenja tanzimatskih reformi te je takva praksa mogla u Bosni biti primjenjivana najkasnije do konačnog kraja timarskog sistema u Bosni i akcije Omer-paše Latasa, što će biti detaljnije obrađeno u narednom poglavlju.

$\mathrm{Na}$ osnovu svega navedenog može se zaključiti da ukidanje vlaških poreza i paušalnih podavanja te prijelaz na režim desetine ne može biti u cjelini sagledano, ukoliko se ne uzme u obzir i "timarski sektor", odnosno zemljišta na kojima su te daće ubirali zaimi i timarnici. Dostupni podaci pokazuju da ne postoji jedinstveno rješenje za sve timare i zeamete te da je na nekim od njih u 18. stoljeću došlo do navedene promjene u režimu ubiranja državnih prihoda, dok je drugdje do tanzimatskih reformi zadržan tradicionalni sistem ubiranja filurije, bez obzira na finansijske teškoće koje je on proizvodio timarnicima, kao i samovolju koju su oni pokazali kako bi riješili probleme koje su imali. Za sada, nema podataka o nekoj masovnoj akciji prevođenja timara i zeameta na režim desetine u 18. stoljeću, kao što je to slučaj s državnim mukatama, ali oni primjeri koji su prikazani u ovom poglavlju izuzetno su važni, jer omogućavaju da se i timarski sektor poveže s navedenim transformacijskim procesima, kao i zbog toga što daju nove podatke koji dokazuju postepenost i dugotrajnost prijelaza na režim desetine u Bosanskom ejaletu.

\footnotetext{
${ }^{97}$ Spahije Islam i Hasan, iz sela Krupa, izdali su 1827/28. (1243. AH) tapiju za zemljište na koju je trebalo plaćati filuriju. GHB, A-4855/TO-777.
} 


\section{Kraj jedne finansijske epohe u Bosni: Mehmed Tahir-pašino doba i akcija Omer-paše Latasa}

Razgovor o transformacijskim procesima u ekonomskoj povijesti Bosanskog ejaleta u osnovi predstavlja diskusiju o kontinuitetima i diskontinuitetima kroz koje je ekonomski sektor navedene provincije prošao tokom višestoljetne osmanske vlasti, pri čemu ključni značaj ima istraživanje dinamike određenog procesa, njegove razvojne faze te posebno "tačke prekida”, u kojima dolazi do napuštanja određene prakse i početka nekog novog kontinuiteta. Do sada je u ovom radu pokazano da je, kada govorimo o ukidanju vlaških poreza i prijelazu na režim desetine, moguće govoriti o više tački prekida u kojoj su filurija i paušalni iznosi napušteni na pojedinim zemljišnim jedinicama, što bi moglo predstavljati neku lokalnu prijelomnu tačku, odnosno prekid s određenom praksom na mikrorazini. Navedene su tačke bile izuzetno važne, jer omogućavaju da se o prijelazu na režim desetine počne govoriti kao o dugotrajnom procesu; no, postavlja se pitanje kada se desio kraj tog procesa, odnosno kada se na institucionalnoj ili makrorazini upotpunosti napušta filurija kao porez, te kada su sva državna zemljišta bila prevedena na režim desetine?

Do sada, u historiografiji se došlo do važnog zaključka da je filurije i podavanja određenih odsjekom na mnogim mjestima u Bosni bilo sve do Tahir-pašinog vremena (1847-1850), a da je krajnje vrijeme do kojeg su se neke stare finansijske prakse ovog tipa mogle pojavljivati na terenu bila akcija carskog mušira Omer-paše Latasa 1851/52..$^{98}$ Dokazivanje ovoga uglavnom se fokusiralo na popis desetine koji je u 1848/49. napravio Mehmed Tahir-paša, odnosno na popise desetine koji su nastali u periodu od 1850. do 1852. Navedeni tekstovi izuzetno su značajni i u historiografiji je s pravom zaključeno da u ovom periodu treba tražiti kraj filurije, ali je važno napomenuti da se prilikom dokazivanja te teze uglavnom fokusiralo na desetinu, te se nijednom nije pozvalo na neki konkretan izvor u kojem se spominje kraj filurije. Metodološki gledano, zaključci o ubiranju filurije

\footnotetext{
${ }^{98}$ A. Aličić, "Desetina”, 130, 133, 134.
} 
u Bosni biće bolje argumentirani ako se ukaže i na tekstove koji direktno govore o ukidanju filurije, a ne samo na one izvore kojima je u prvom planu bilo zavođenje desetine.

Ključni dokaz da je filurija na nekim mjestima ubirana do Mehmed Tahir-pašinog vremena predstavljaju potvrde državnih službenika o plaćenoj filuriji. Međutim, nije se tu radilo o visini filurije koja je bila zabilježena $\mathrm{u}$ katastarskim popisnim defterima, nego o filuriji koja se sastojala iz dva dijela - od starog iznosa filurije te dodatne filurije, (kadîm ve zamm filûrî), koja je, u skladu s ranije opisanim mjerama iz tridesetih godina 19. stoljeća bila nametnuta, kako bi se dostigao iznos koji bi bio ekvivalentan desetini. Na terenu, posljednju potvrdu ovog tipa pronašao sam za 1847. godinu..$^{99} \mathrm{Ne}$ može se reći da je ona zadnja potvrda ovog tipa, ali je jasno da se radilo o jednoj od zadnjih potvrda, budući da je filurija uskoro upotpunosti napuštena.

Podatke koji pokazuju da je 1848/49. (1265. AH) došlo do prevođenja filurijskih zemljišta na režim desetine, moguće je susresti u nekoliko dokumenata koji su nastali 1850. Naprimjer, u jednoj Mehmed Tahir-pašinoj bujuruldiji iz marta 1850. navodi se da se naturalni "ušur" (aynen öşrr), u visini od jednog desetog dijela (onda bir), sakuplja na zemljištima u Bosanskom ejaletu na kojima "do sada" (şimdiye kadar) nije bilo naturalne desetine, nego su uzimani filurija i novčani "ekvivalent za desetinu" (bedel-i öşr). Dodatno je pojašnjeno da se "novac" (akçe) koji je u prošloj 1265. AH [1848/49.] sakupljen od takvog "desetinskog prihoda" namijeni za popravke topovskih kundaka u bosanskih tvrđavama. ${ }^{100}$

Prema tome, očigledno je da je 1848/49. (1265. AH) bila godina u kojoj je vlast računala na neki novčani prihod od zemljišta koja su prevedena sa režima filurije i novčanog ekvivalenta za desetinu na naturalnu desetinu. Postavlja se pitanje o kakvom se novcu radilo i šta nam ovo govori o osmanskim finansijskim praksama.

\footnotetext{
${ }^{99}$ Riječ je o poreskoj potvrdi iz 1847. godine, prema kojoj je Sabit-aga Đumišić državi (cânib-i mîrîye) platio 106 groša i 16 para na ime "stare i dodatne filurije" (kadîm ve zamm filûrîsi). GHB, A-4855/TO-767.

${ }^{100}$ GHB, Sidžil 85, 55-56.
} 
Novac na koji je vlast računala bila je zakupnina, a sve ovo ukazuje na to da su nekadašnja filurijska zemljišta u Bosni, čim su prevedena na naturalnu desetinu, bila izdata u zakup, te da je vlast novac koji je stekla na taj način odmah usmjerila u vojne svrhe. Podaci o izdavanju navedenih prihoda u zakup bili su poznati Muvekkitu, ${ }^{101}$ koji je bio suvremenik ovih događaja i tradicionalni historičar. Dodatni dokaz za ovo pitanje predstavljaju finansijski registri državne vlasti, u kojima je 1850. (1266. AH) zabilježeno da su određene ugledne osobe uzele u zakup (iltizâm) desetinu zemljišta u Bosanskom ejaletu na kojima do sada nije ubirana desetina, nego su bila pod filurijom i novčanim ekvivalentom za desetinu. Zakupna cijena iznosila je “5.000 kesa”, dok je svrha utroška tog novca navedena identično kao i u ranije spomenutoj Mehmed-pašinoj bujuruldiji - trebalo je popraviti tvrđavske kundake u bosanskim tvrđavama. ${ }^{102}$

Navedeni dokumenti pokazuju da je u Mehmed Tahir-pašino vrijeme u Bosni okončano plaćanje filurije na većem broju zemljišnih jedinica, te da je ovo doba bilo "tačka prekida" za ovaj porez na mnogim mjestima u Bosanskom ejaletu. Nije naveden broj baština na kojima se desila ova promjena, ali visina spomenute zakupne cijene ukazuje na to da se moralo raditi o nekom većem broju. Međutim, postavlja se pitanje da li je i nakon toga bilo podavanja pod ovim imenom. Aličić je utvrdio da osmanski popisi desetine napravljeni između 1850-1852. na pojedinim mjestima navode filuriju te da su neka od tih mjesta ista ona zemljišta na kojima je tradicionalno ubiran ovaj porez. ${ }^{103}$ Zasada, teško je znati da li je to konkretno naplaćivano na terenu, odnosno donošenje konkretnih zaključaka o ovome zahtijevalo bi uvid u poreske potvrde iz ovog perioda. U svakom slučaju,

\footnotetext{
${ }^{101}$ Salih Sidki Hadžihusejnović Muvekkit, Povijest Bosne 2, preveo Abdulah Polimac, Sarajevo: ElKalem, 1999, 1030.

${ }^{102}$ Bilješka o ovom pitanju datirana je 13. februara 1850. (30. rebiu-l-evvel 1266. AH). BOA, KK.d 5859, fol. 2 r.

${ }^{103}$ Naprimjer, u državnim popisima desetine iz 1851/52. (1867. AH) i 1851/52. (1268. AH), spominju se, između ostalih, u kazama Jajce, Banjaluka i Tešanj neki prihodi od filurije. Na ovim je područjima tradicionalno bila rasprostranjena filurija. Neki od tih prihoda bili su u okviru mukata, dok je dio bio u sastavu timara. A. Aličić, "Desetina”, 162, 164, 166.
} 
jasno je da je Omer-paša Latas ukinuo 1851/52. timarski sistem u Bosni te je to vrijeme, po svemu sudeći, najkasniji period do kojeg bi se eventualno mogli tražiti "ostaci ostataka" filurije kao poreza.

Na koncu, može se zaključiti da su eliminiranje filurije u Bosanskom ejaletu, kao i njeno mijenjanje desetinom, koji su se odigrali u Mehmed Tahir-pašino i Omer-pašino doba, predstavljali samo završnu fazu dugog procesa ukidanja filurije i paušalnih novčanih daća. Provedba ove mjere je označila konačni kraj ubiranja navedenih izvora državnih prihoda koji su stoljećima bili prisutni na Balkanu. Spomenuta promjena, zajedno s drugim reformama koje su se desile krajem četrdesetih i početkom pedesetih godina 19. stoljeća, kao što su ukidanje običajnih poreza, zavođenje reformskog poreza pod imenom vergija (virgü-yi mahsûsa ili an cemấatin virgü) te ukidanje timarskog sistema, daje osnovu za zaključak da navedeno vrijeme treba shvaćati kao kraj jedne epohe u provincijskim finansijama Bosanskog ejaleta, odnosno kao početak novog razdoblja u ekonomskoj povijesti navedenog prostora.

\section{Zaključak}

Analiza osmanske finansijske građe te usporedba podataka, koji se u njoj pronalaze sa tvrdnjama koje se susreću u historiografiji, pokazala je da dominantni stavovi u literaturi koja se bavila transformacijskim procesima u Osmanskom Carstvu u periodu od početka 17. stoljeća do tanzimatskih reformi nisu dostatni da objasne sve manifestacije transformacijskih procesa u osmanskoj Bosni. Došlo se do zaključka da je potrebno rekonceptualizirati ideju šta se sve treba smatrati transformacijskim procesima u osmanskoj povijesti, te da je u ovom pogledu nedovoljno istraženo polje provincijskih finansija. Dosadašnja historiografija koja se bavila fiskalnom transformacijom fokusirala se primarno na reforme džizje i izvanrednih poreza, promjene u sistemu zakupa poreza, uvođenje novih poreza, kao što su mirnodopska i ratna pomoć, kao i promjenu načina distribucije poreskog tereta i uvođenje tevzi deftera. Ovim radom se pokazuje da, pored 
svega navedenog, razgovor o transformaciji na fiskalnom polju u Bosanskom ejaletu treba obuhvaćati i proces ukidanja vlaških poreza, odnosno filurije, kao i paušalnih novčanih daća, te proces prevođenja baština koje su bile opterećene ovim podavanjima na sistem naturalne desetine. Navedena pojava praćena je ovdje kroz primarne izvore od kraja 17. stoljeća do vremena implementacije tanzimatskih reformi polovinom 19. stoljeća.

Rekonceptualizirano je i pitanje načina na koji treba označavati ukidanje vlaških poreza i paušalnih daća te prijelaz na režim desetine. Ovim radom se predlaže da se pojedinačni primjeri navedene povijesne pojave promatraju kao dio šireg procesa. Dosadašnja historiografija prijelaz na desetinu vezivala je uglavnom za 19. stoljeće, pri čemu se nije govorilo o procesu, nego se samo predstavljao fenomen, koji je najčešće bio vezivan za tanzimatske reforme ili razdoblje koje je neposredno prethodilo tanzimatu. Za razliku od toga, u ovom istraživanju pokazani su primjeri koji nedvojbeno dokazuju da je prevođenje na režim desetine u Bosanskom ejaletu predstavljalo dugotrajni proces te da su se samo njegove završne faze odvijale polovinom 19. stoljeća. Prije toga, kao posebno značajne faze navedenog procesa, u ovom radu su istaknute akcije prevođenja državnih mukata na režim desetine koje su izvršene krajem 17. i početkom 18. stoljeća, kao i tridesetih godina 19. stoljeća. Također, donijeti su i primjeri koji pokazuju da je prijelaza na režim desetine u Bosanskom ejaletu bilo i izvan ovih godina, kako na mukatama, tako i na zemlji koja je ulazila u sastav timara i zeameta.

Rezultat ovog rada je i to što su prikazani uzroci koji su ponukali osmansku vlast da prevodi zemljišta pod filurijom i podavanjima odsjekom na naturalnu desetinu, kao i društveno-ekonomske posljedice toga. Na prvom mjestu, treba imati u vidu fiskalni razlog, odnosno pokazano je da je filurija u monetarnim prilikama 18. i 19. stoljeća donosila manji prihod državi nego desetina, te da se ovom mjerom nastojalo podići razinu državnog prihoda što je, s druge strane, povećalo i atraktivnost ovih mukata za buduće zakupce. Na mnogim zemljištima, ipak, bio je zadržan stari režim ubiranja vlaških poreza i podavanja odsjekom, što je doprinosilo tome da zakupci i 
timarnici pokušavaju samovoljno uvesti desetinu ili povećati iznos filurije, što je država redovno zabranjivala.

Odluka vlasti da ukine filuriju i prevede određena zemljišta na režim desetine dovela je do strukturalnih promjena u provincijskim finansijama. Navedeni izraz se u ovom radu prvi put koristi za promjene u ekonomiji Bosanskog ejaleta, pod utjecajem ekonomske literature, te je i on važna novina u načinu historiografskog tumačenja transformacijskih promjena.

Kada je riječ o društveno-ekonomskim posljedicama procesa prijelaza na režim desetine, utvrđeno je da je on utjecao na život lokalnog stanovništva. Njegove posljedice osjetili su oni koji su se finansirali od prihoda koji je stjecan na osnovu izdavanja u zakup zemljišta koja su prevedena na desetinu - posadnici tvrđava u Bosanskom ejaletu, ali i određene osobe iz ulemanskog sloja. Navedeni proces značajan je za razumijevanje ekonomskih aktivnosti zakupnika, kao i osoba koje su uzimale navedene državne prihode u podzakup, ali i za shvaćanje životnog standarda posjednika zemljišnih čestica koje su bile opterećene podavanjima, raji, kao i o posjednicima čifluka iz reda vojničke klase.

Kada je riječ o posljedicama za druge oblasti ekonomije, pokazalo se da je zamjena filurije, kao novčane daće, naturalnom desetinom djelovala destimulativno za ekonomsku razmjenu na tržištu poljoprivrednih proizvoda u Bosanskom ejaletu, budući da su, zahvaljujući tome, posjednici mogli izvršavati svoje obaveze prema državi bez izlaska na tržište i prodaje poljoprivrednih proizvoda.

$\mathrm{Na}$ koncu, važan zaključak do kog se došlo u ovom istraživanju je da razumijevanje osmanskih transformacijskih procesa ne može biti isključivo fokusirano na državni centar, niti na finansije pojedinih provincija. Da bi se steklo temeljitije znanje o ovome i izbjegle određene neopravdane generalizacije koje se primjećuju u historiografiji, potrebno je istražiti izvore koji se odnose na različite dijelove Osmanskog Carstva. Ovaj put, riječ je bila o jednom važnom pitanju koje se odnosi na Bosanski ejalet, no stanje izvora je takvo da su nova istraživanja načina na koje su se manifestirali 
transformacijski procesi u Osmanskom Carstvu u 18. i 19. stoljeću mogući, ali ujedno i potrebni.

\title{
IZVORI I LITERATURA
}

\author{
Arhivski izvori
}

\section{Türkiye Cumhuriyeti Cumhurbaşkanlığı Devlet Arşivleri Başkanlığı \\ Osmanlı Arşivi (BOA), Istanbul, Republika Turska}

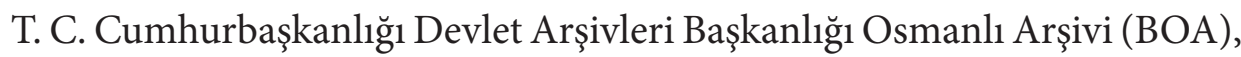
Istanbul - Maliyeden Müdevver (MAD.d): 560, 768, 1399, 2467, 3420, 4718, 10172, 16064.

T. C. Cumhurbaşkanlığı Devlet Arşivleri Başkanlığı Osmanlı Arşivi (BOA), Istanbul - Tapu Tahrir Defteri (TD): 24, 144, 260, 533, 743.

T. C. Cumhurbaşkanlığg Devlet Arşivleri Başkanlığı Osmanlı Arşivi (BOA), Istanbul - Kamil Kepeci (KK.d): 1981, 5859.

T. C. Cumhurbaşkanlığı Devlet Arşivleri Başkanlığı Osmanlı Arşivi (BOA), Istanbul - Cevdet, Maliye (C.ML): 6860, 10182,10074, 14885, 23446, 29676, 30260, 30261.

T. C. Cumhurbaşkanlığg Devlet Arşivleri Başkanlığı Osmanlı Arşivi (BOA), Istanbul - Bâb-1 Asafî, Dîvân-1 Hümâyûn Sicilleri, Ahkâm-1 Bosna (A.DVNS.AHK.BN.d): 1.

T. C. Cumhurbaşkanlığg Devlet Arşivleri Başkanlığı Osmanlı Arşivi (BOA), Istanbul - Bâb-1 Defterî, Başmuhasebe defterleri (D.BŞM.d): 483.

T. C. Cumhurbaşkanlığı Devlet Arşivleri Başkanlığı Osmanlı Arşivi (BOA), Istanbul - Bâb-1 Defterî, Başmuhasebe, Bosna hazinesi defterleri (D.BŞM.BNH.d): 16771, 16777.

T. C. Cumhurbaşkanlığı Devlet Arşivleri Başkanlığg Osmanlı Arşivi (BOA), Istanbul - Bâb-1 Defterî, Başmuhasebe, Bosna hazinesi (D.BŞM.BNH): $7 / 5$. 


\section{Gazi Husrev-begova biblioteka (GHB), Sarajevo}

Zbirka osmanskih dokumenata (A): 4772/T0, 4773/TO, 4855/TO-30, 4855/T0-32, 4855/TO- 102, 4855/T0-607, 4855/TO-616, 4855/TO-629, 4855/TO-777.

Zbirka sidžila: 75, 76, 85 .

Arhiv Bosne i Hercegovine (ABiH), Sarajevo

Zbirka otkupa i poklona (ZPO): 26.

\section{Objavljeni izvori}

Bojanić, Dušanka i Katić, Tatjana (prev.), Maglajski sidžili 1816-1840, Sarajevo: Bošnjački institut Fondacija Adila Zulfikarpašića, 2005.

Bojanić, Dušanka (prev.), Turski zakoni i zakonski propisi iz XV i XVI veka za smederevsku, kruševačku i vidinsku oblast, Beograd: Istorijski institut, 1974.

Kupusović, Amina (prev.), Opširni popis Bosanskog sandžaka iz 1604. godine, sv. 4. Sarajevo: Bošnjački institut Zürich - Odjel Sarajevo i Orijentalni institut u Sarajevu, 2000.

Muvekkit, Salih Sidki Hadžihusejnović, Povijest Bosne 2, preveo Abdulah Polimac, Sarajevo: El-Kalem, 1999.

\section{Literatura}

\section{Knjige}

Barkey, Karen, The Empire of Difference: The Ottomans in Comparative Perspective, Cambridge: Cambridge University Press, 2008.

Cezar, Yavuz, Osmanlı Maliyesinde Bunalım ve Değişim Dönemi: (XVIII. yy dan Tanzimat’a Mali Tarih, Istanbul: Alan Yayıncılık, 1986.

Baki, Çakır, Osmanlı Mukataa Sistemi (XVI-XVIII Yüzyıl), Istanbul: Kitabevi, 2003.

Eren, Ahmet Cevat, Mahmud II. Zamanında Bosna-Hersek, Istanbul: Nurgök Matbaası, 1965. 
Handžić, Adem, Tuzla i njena okolina, Sarajevo: Svjetlost, 1975.

Moačanin, Nenad, Turska Hrvatska, Zagreb: Matica Hrvatska, 1999.

Redhouse, James W, A Turkish and English Lexicon: Shewing in English the Significations of the Turkish Terms, Constantinople: American Mission, 1890.

\section{Članci}

Aličić, Ahmed S, “Desetina u Bosni polovinom XIX vijeka”, u: Prilozi, sv. 16, br. 17, Sarajevo: Institut za istoriju, 1980, 129-174.

Ágoston, Gábor, "Military Transformation in the Ottoman Empire and Russia, 1500-1800", u: Kritika: Explorations in Russian and Eurasian History, sv. 12, br. 2, Bloomington, IN: Slavica Publishers, Indiana University, 2011, 281-319.

Barbir, Karl, "The Changing Face of the Ottoman Empire in the Eighteenth Century: Past and Future Scholarship", Oriente Moderno, sv. 18 (79), br. 1, Rim: Istituto per l'Oriente C. A. Nallino, 1999, 253-267.

Buzov, Snježana, "Vlasi u bosanskom sandžaku i islamizacija", u: Prilozi za orijentalnu filologiju, sv. 41, Sarajevo: Orijentalni institut, 1991, 99-111.

Cezar, Yavuz, "From Financial Crisis to Structural Change: The Case of the Ottoman Empire in the Eighteenth Century", u: Oriente Moderno, Nuova serie, sv. 18 (79), br. 1, Rim: Istituto per l'Oriente C. A. Nallino, 1999, 49-54.

Faroqhi, Suraiya, "Crisis and Change, 1590-1699", u: An Economic and Social History of the Ottoman Empire. Volume 2: 1600-1914, ur. Halil İnalc1k i Donald Quataert, Cambridge: Cambridge University Press, 1997, 411-636.

Filipović, Nedim, "Pogled na osmanski feudalizam”, u: Godišnjak Istorijskog društva Bosne i Hercegovine, sv. 4, Sarajevo: Istorijsko društvo Bosne i Hercegovine, 1952, 5-146.

Filipović, Nedim, "Vlasi i uspostava timarskog sistema u Hercegovini", u: Godišnjak, sv. 12/10, Sarajevo: Centar za balkanološka istraživanja, ANUBiH, 1974, 127-221. 
İnalc1k, Halil, "Military and Fiscal Transformation in the Ottoman Empire, 1600-1700", u: Archivum Ottomanicum, sv. VI, Wiesbaden: Harrasowitz, 1980, 283-337.

İnalcik, Halil, "Saraybosna Şer’iyye Sicillerine Göre Viyana Bozgunundan Sonraki Harb Yillarında Bosna", u: Tarih Vesikaları, sv. 2, br. 11, Ankara: Maar'f Vekilliği, 1943, 372-383.

Kasumović, Fahd, “Osmanska agrarna politika i nadmetanje za zemlju u jugoistočnoj Evropi (analiza čifluka u Bosanskom sandžaku od uspostavljanja osmanske vlasti do početka 17. stoljeća)”, u: Anali Gazi Husrev-begove biblioteke, sv. 35, Sarajevo: Gazi Husrev-begova biblioteka, 2014, 93-150.

Kursar, Vjeran, "Being an Ottoman Vlach: On Vlach Identity (Ies), Role and Status in Western Parts of the Ottoman Balkans (15th -18th Centuries)", u: OTAM, sv. 34, Ankara: Ankara Üniversitesi Basımevi, 2013, 115-161.

Matkovski, Aleksandar, "Stočarski danak - filurija”, u: Arhivski vjesnik, br. 33, Zagreb: Hrvatski državni arhiv, 1990, 71-77.

Mulić, Jusuf, "Društveni i ekonomski položaj Vlaha i Arbanasa u Bosni pod osmanskom vlašću", u: Prilozi za orijentalnu filologiju, sv. 51, Sarajevo: Orijentalni institut, 2011, 111-146.

Sućeska, Avdo, "Pokušaji muslimanske raje u Bosni da se oslobode rajinskog statusa u XVIII stoljeću”, u: Dijalog - Časopis za filozofiju i društve$n u$ teoriju, br. 1-2, Zagreb: Filozofsko teološki institut Družbe Isusove u Zagrebu, 2003, 191-201.

Sućeska, Avdo, "Uticaj austro-turskih ratova na opterećivanje stanovništva u Bosni u XVIII stoljeću”, u: Godišnjak Pravnog fakulteta u Sarajevu, sv. 27, Sarajevo: Pravni fakultet u Sarajevu, 1980, 197-207.

Truhelka, Ćiro, "O podrijetlu žiteljstva grčkoistočne vjeroispovijesti u Bosni i Hercegovini (1941)", u: Vlasi u starijoj hrvatskoj historiografiji, ur. Ivan Mužić, Split: Muzej hrvatskih arheoloških spomenika, 2010, 119-132. 


\title{
TRANSFORMATION PROCESSES IN THE PERIPHERY OF THE OTTOMAN EMPIRE REVISITED: THE FILURI TAX AND TRANSITION TO THE TITHE SYSTEM IN THE AGRICULTURAL ECONOMY OF OTTOMAN BOSNIA, C. 1699-1852
}

\begin{abstract}
Summary
The dominant historiographic images on the fiscal transformation in the Ottoman Empire have established that the $17^{\text {th }}$ and $18^{\text {th }}$ century in Ottoman history should not just be described as an age of crisis but also as a period that witnessed a significant fiscal transformation that gradually changed the face of the Ottoman finance. This idea has mostly been supported by the changes in the collection of extraordinary taxes, the poll tax, and tax farm reforms, as well as by the introduction of the imdâdiyye taxes and the apportionment of tax burden through the cooperation of judges $(\mathrm{kad} \imath$ ) and local social elites (ayân). Although these reforms were undeniably important, the mentioned historiographic ideas are insufficient to describe all of the structural changes that occurred in the peripheral regions of the Ottoman Empire as was the frontier province of Bosnia. This paper argues that the very idea of what should be considered under the umbrella of transformation processes in the Ottoman Empire should be revisited in the case of Ottoman Bosnia and adjusted to its local financial context. Seeing as the filûrî tax (resm-i filûri) and the lump sum payments $\left(m a k t \hat{u}^{c}\right)$ traditionally were among the most important taxes in the agricultural economy of Ottoman Bosnia, this article proposes that the abolishment of these taxes and their gradual substitution with the in-kind tithe and some other cash payments should also be counted as a part of the fiscal transformation in this region. Based on the primary Ottoman sources, this paper explores various historical phases of this process in the period between 1699 and 1852, starting from the structural change it made
\end{abstract}


in the provincial finance and local economy to the impact it had on the wider social framework. The major authors who have been researching the abolishment of the filuri tax in Bosnia and its substitution with the tithe focussed their attention mostly on the $19^{\text {th }}$-century reforms and thus failed to recognise this phenomenon as a part of the wider process which had much deeper roots than the $19^{\text {th }}$ century. This paper argues that the mentioned topic is heavily under-researched and that archival materials explored in this study could help us achieve not only a better understanding of the financial context of the Ottoman periphery, but also it can lead us to get a clearer image of the complexity of Ottoman political solutions and their active attitude towards dealing with various challenges put before the government by the internal and external developments. 